\title{
El nuevo recurso de casación contencioso- administrativo y el interés casacional objetivo para la formación de la jurisprudencia
}

\author{
Miguel Ángel Recuerda Girela \\ Acreditado a Catedrático de Derecho Administrativo \\ Profesor titular de la Universidad de Granada
}

\begin{abstract}
SUMARIO: I. LAS RECIENTES REFORMAS DE LA LEY DE LAJURISDICGIÓN CONTENGIOSO-ADMINISTRATIVA. -II. LOS MOTIVOS DE LA REFORMA DE LA CASACIÓN GONTENGIOSO-ADMINISTRATIVA. -III. LA ENTRADA EN VIGOR DE LA MODIFICACIÓN. IV. LA SUPRESIÓN DEL REGURSO DE CASACIÓN PARA LA UNIFICAGIÓN DE LA DOGTRINA Y DEL REGURSO DE CASAGIÓN EN INTERÉS DE LA LEY. -V. EL OBJETO DEL RECURSO DE CASACIÓN. -VI. EL ACGESO A LA CASAGIÓN: EL INTERÉS CASAGIONAL OBJETIVO PARA LA FORMAGIÓN DE LA JURISPRUDENCIA. -VII. LAS PRETENSIONES. -VIII. EL PROGEDIMIENTO. -VIII.1. Las condiciones de los escritos. -VIII.2. La preparación del recurso de casación. -VIII.3. La admisión o inadmisión a trámite del recurso. -VIII.4. La interposición del recurso y la oposición. -VIII.5. La vista. -VIII.6. La sentencia. -IX. GONCLUSIONES.
\end{abstract}

RESUMEN: El objeto de este trabajo es analizar la reforma que la Ley Orgánica 7/2015 ha hecho del recurso de casación contencioso-administrativo. La esencia de la reforma radica en que se ha ampliado el objeto de este recurso de casación, se han eliminado los motivos tasados que la ley contemplaba para la admisión del recurso, y se ha establecido un sistema de apreciación discrecional del interés casacional por parte del Tribunal Supremo como requisito para la admisión del recurso.

PALABRAS CLAVE: Tribunal Supremo, recurso de casación, writ of certiorari.

ABSTRACT: The purpose of this paper is to analyze the reform that has been made by the Organic Law 7/2015on the contentius-administrative cassation appeal. 
The essence of this reform lies on that the object of the cassation appeal has been extended, the limited reasons regulated by law for the admission of the appel have been eliminated, and it has been established a system of free discretional assessment of the so called cassation interest as a requisite for the admission of the appeal by the Supreme Court

KEYWORDS: Supreme Court, appeal in cassation, writ of certiorari.

\section{LAS RECIENTES REFORMAS DE LA LEY DE LA JURIS- DICGIÓN GONTENGIOSO-ADMINISTRATIVA}

El objeto de este trabajo es analizar, en una primera aproximación, la importante reforma del recurso de casación contencioso-administrativo que entró en vigor el 22 de julio de 2016 (operada por Ley Orgánica 7/2015, de 21 de julio). La nueva configuración de la casación contencioso-administrativa es la modificación de mayor calado de las siete que experimentó en 2015 la Ley 29/1998, de 13 de julio, reguladora de la Jurisdicción Contencioso-Administrativa ("LJCA") ${ }^{1}$, , pues no se trata de una modificación puntual del recurso, sino de la introducción de un nuevo modelo de recurso de casación. A continuación, señalo, muy sucintamente, dichas reformas de la LJCA:

(i) La Ley Orgánica 3/2015, en su apartado diez del artículo segundo, creó un procedimiento para la declaración judicial de extinción de partidos políticos que se ha introducido como artículo 12 bis de la Ley Orgánica 6/2002, de 27 de junio, de Partidos Políticos. Con motivo de la creación de este procedimiento judicial, la disposición final segunda de la Ley Orgánica 3/2015 ha ampliado las competencias de los Juzgados Centrales de lo Contencioso-Administrativo al conocimiento de este procedimiento judicial, que se ha añadido como apartado 3 del artículo 9 de la LJCA.

* El autor agradece a José Antonio García-Trevijano Garnica sus comentarios sobre la versión previa de este trabajo.

1 Las referidas modificaciones de la LJCA se han llevado a cabo mediante las siguientes leyes: (i) la Ley Orgánica 3/2015, de 30 de marzo, que modifica la Ley Orgánica 8/2008, de 4 de julio, sobre financiación de los Partidos Políticos; (ii) la Ley 11/2015, de 18 de julio, de recuperación y resolución de entidades de crédito y empresas de servicios de inversión; (iii) la Ley 26/2015, de 28 de julio, que modifica el sistema de protección a la infancia y a la adolescencia; (iv) la Ley Orgánica 7/2015, de 21 de julio, que modifica la Ley Orgánica 6/1985, de 1 de julio, del Poder Judicial; (v) la Ley 42/2015, de 5 de octubre, de reforma de la Ley 1/2000, de 7 de enero, de Enjuiciamiento Civil; (vi) la Ley 34/2015, de 21 de septiembre, de modificación parcial de la Ley 58/2003, de 17 de diciembre, General Tributaria; y (vii) la Ley 22/2015, de 20 de julio, de Auditoría de Cuentas. Un estudio sobre esas modificaciones, aunque no analiza el recurso de casación en detalle, puede verse en RECUERDA GIRELA, M.A., "Siete reformas de la Ley Reguladora de la Jurisdicción Contencioso-Administrativa”, en REGUERDA GIRELA, M.A. (dir.), Problemas Prácticos y Actualidad del Derecho Administrativo. Anuario de Derecho Administrativo 2016, Thomson Reuters Civitas, 2016, págs. 29 a 45. 
(ii) La disposición final tercera de la Ley 11/2015 ha modificado la letra g) del apartado 1 del artículo 11 de la LJCA. Con esta reforma, la Sala de lo Contencioso-Administrativo de la Audiencia Nacional es competente para conocer de los recursos contra los actos del Banco de España, de la Comisión Nacional del Mercado de Valores y del Fondo de Reestructuración Ordenada Bancaria (FROB) adoptados conforme a lo previsto en la Ley 11/2015, de 18 de junio, de recuperación y resolución de entidades de crédito y empresas de servicios de inversión.

(iii) Dado que la Ley 26/2015 atribuye a los Juzgados de Primera Instancia la oposición a las resoluciones en materia de protección de menores, la disposición final primera de la Ley 26/2015 ha modificado el apartado 6 del artículo 8 de la LJCA sobre competencias que tenían en esa materia los Juzgados de lo Contencioso-administrativo. También ha suprimido la competencia de dichos Juzgados para autorizar la entrada en domicilios y demás lugares cuyo acceso requiera el consentimiento del titular, en el caso de que se pretenda la ejecución de medidas de protección de menores que hayan sido acordadas por la Entidad Pública competente en la materia.

(iv) El nuevo apartado 3 del artículo 108 de la LJCA, introducido por la Ley Orgánica 7/2015, ha regulado la ejecución de sentencias de demolición de inmuebles construidos ilegalmente ${ }^{2}$.

(v) Ley Orgánica 7/2015 ha añadido al artículo 102 de la LJCA un nuevo motivo para la revisión de sentencias como cauce de ejecución de las sentencias del Tribunal Europeo de Derechos Humanos, pues tal ejecución no encontraba claro encaje en nuestro sistema jurídico.

(vi) La disposición final cuarta de la Ley 42/2015 ha añadido un apartado 3 al artículo 23 de la LJCA, que permitirá de nuevo a los funcionarios comparecer por sí mismos en defensa de sus derechos estatutarios, cuando se debata sobre cuestiones de personal que no impliquen separación de empleados públicos inamovibles (lo que ya fue así durante un tiempo).

(vii) La disposición final tercera de la Ley 34/2015 ha añadido una disposición adicional novena a la LJCA para tener en cuenta ciertas incidencias de las decisiones

2 Vid. GONZÁLEZ BOTIJA, F. y RUÍZ LÓPEZ, M.A., "La ejecución de sentencias de derribo y los terceros de buena fe (a propósito del nuevo artículo 108.3 de la Ley de la Jurisdicción ContenciosoAdministrativa)", Revista de urbanismo y edificación, núm. 35, 2015, págs. 23-45; BARDAJÍ PASCUAL, G., "Sobre el nuevo apartado 3 del artículo 108 de la Ley Reguladora de la Jurisdicción ContenciosoAdministrativa relativo a la demolición de construcciones declaradas ilegales por sentencia", en RECUERDA GIRELA, M.A. (dir.), Problemas ... op.cit., págs. 742 a 758. 
de las instituciones de la Unión Europea en actos administrativos relativos a deudas aduaneras. Igualmente, esa disposición final recuerda que no corresponde al orden jurisdiccional contencioso-administrativo conocer de las pretensiones que se deduzcan respecto de ciertas actuaciones tributarias vinculadas a delitos contra la Hacienda Pública. Además, señala que una vez que se inicie el proceso, tampoco corresponderá al orden jurisdiccional contencioso-administrativo conocer las pretensiones que se deduzcan respecto de las medidas cautelares adoptadas al amparo del artículo 81 de la LGT.

(viii) La disposición final tercera de la Ley 22/2015 ha ampliado el objeto del recurso contencioso-administrativo. En concreto, ha añadido, en el apartado 6 de la disposición adicional 4 de la LJCA, las resoluciones del Ministerio de Economía y Competitividad (actualmente, Ministerio de Economía, Industria y Competitividad) ${ }^{3}$ que resuelvan recursos de alzada contra actos dictados por el Instituto de Contabilidad y Auditoría de Cuentas, así como la impugnabilidad directa, ante la Sala de lo Contencioso-Administrativo de la Audiencia Nacional, de las resoluciones de carácter normativo dictadas por el Instituto de Contabilidad y Auditoría de Cuentas.

(ix) Y finalmente, se ha modificado el régimen del recurso de casación contencioso-administrativo, al que me referiré en los siguientes apartados.

No parece normal, ni aconsejable para la seguridad jurídica, tanta reforma de una misma ley en un solo año, pues se podría evitar ese tipo de inestabilidad normativa que dificulta innecesariamente el conocimiento de las normas vigentes. Sorprende la falta de previsión de quienes tienen la responsabilidad de legislar, que olvidan corrientemente que al modificar el ordenamiento jurídico no solo es importante la finalidad que se persigue con la reforma material de las normas, sino también la forma y el tiempo en que ésta se produce para lograr la simplificación del ordenamiento, la seguridad jurídica y la claridad normativa ${ }^{4}$.

3 Real Decreto 415/2016, de 3 de noviembre, por el que se reestructuran los departamentos ministeriales.

4 Sobre la seguridad jurídica en relación con la producción normativa, la STG(Pleno) núm. 101/2013, de 23 de abril (RTC 2013\101), dice lo siguiente: "En efecto, la seguridad jurídica, de conformidad con nuestra doctrina, ha de entenderse como la certeza sobre el ordenamiento jurídico aplicable y los intereses jurídicamente tutelados, procurando «la claridad y no la confusión normativa» (STC 46/1990, de 15 de marzo [RTC 1990, 46], FJ 4), de tal manera que «sólo si en el ordenamiento jurídico en que se insertan, y teniendo en cuenta las reglas de interpretación admisibles en Derecho, el contenido o las omisiones de un texto normativo produjeran confusión o dudas que generaran en sus destinatarios una incertidumbre razonablemente insuperable acerca de la conducta exigible para su cumplimiento o sobre la previsibilidad de sus efectos, podría concluirse que la norma infringe el principio de seguridad jurídica» (SSTC 150/1990, de 4 de octubre [RTC 1990, 150], FJ 8; 142/1993, de 22 de abril [RTC 1993, 142], FJ 4; 212/1996, de 19 de diciembre [RTC 1996, 212], FJ 15; y 96/2002, de 25 de abril [RTC 2002, 96], FJ 5)". 
Por otro lado, se ha dicho que la modificación normativa a través de normas que tienen un título y objeto distinto al de la norma que se pretende modificar, supone una deficiente técnica legislativa, pues oscurece el ordenamiento jurídico y hace más compleja la localización del texto vigente. Sin embargo, el fenómeno habitual de las normas intrusas o "cavaliers legislatifs", a las que se refiere García-Escudero", es una práctica que, según el Tribunal Constitucional, no lesiona el principio de seguridad jurídica, salvo en relación con la Ley de Presupuestos (SSTC 76/1992 y 83/1993, entre otras), en la que existen razones que no son extensibles a todas las normas. Cabe recordar, en palabras del Tribunal Constitucional, que los principios de seguridad jurídica y de interdicción de la arbitrariedad de los poderes públicos exigen que la norma sea clara para que los ciudadanos sepan a qué atenerse ante la misma, y, en este orden de exigencias, no puede subestimarse la importancia que para la certeza del Derecho y la seguridad jurídica tiene el empleo de una depurada técnica jurídica en el proceso de elaboración de las normas (STC núm. 150/1990, de 4 de octubre [RTG 1990\150]). Por fortuna, el desorden del legislador, que se convirtió en oportunidad de negocio para las editoriales jurídicas, está siendo paliado por la Administración a través de diversos medios como la publicación electrónica de los boletines oficiales, la consolidación de la legislación vigente, el envío de alertas legislativas por correo electrónico, la publicación electrónica de códigos, etc. La Agencia Estatal del Boletín Oficial del Estado ha dado un paso de gigante en esta materia en los últimos años, aunque se echa en falta un trabajo coordinado y al mismo ritmo de desarrollo con todos los boletines oficiales españoles y con el Diario Oficial de la Unión Europea, imprescindible para conocer la legislación vigente de fuentes oficiales.

Señalado lo anterior, y sin mayor preámbulo, se analizarán las importantes modificaciones que afectan al recurso de casación contencioso-administrativo.

\section{LOS MOTIVOS DE LA REFORMA DE LA CASACIÓN CON- TENCIOSO-ADMINISTRATIVA}

La disposición final tercera de la Ley Orgánica 7/2015 ha suprimido la Sección 5 del Capítulo III del Título IV, la Sección 4 del Capítulo III del Título IV, y los artículos 94 a 101 de la LJCA; además, ha modificado los artículos 86, 87, 88, 89, 90, 91, 92, 93 y 139, y ha añadido el artículo 87 bis. Todo ello supone una reforma sustancial del recurso de casación contencioso-administrativo, y un cambio de modelo en el que lo más relevante es que la admisibilidad del recurso no dependerá de su cuantía,

5 GARCÍA-ESGUDERO MÁRQUEZ, P., "Técnica legislativa y seguridad jurídica en la jurídica en la jurisprudencia constitucional", en ARANA GARCÍA, E., Algunos problemas actuales de técnica legislativa, Thomson Reuters Aranzadi, 2015, págs. 95 y 96. 
como en el sistema anterior sino de la concurrencia en el asunto de lo que ha dado en llamarse "interés casacional". El interés casacional es, por tanto, un requisito imprescindible para la admisión del recurso de casación.

El motivo declarado por el legislador, en la Exposición de Motivos de dicha Ley Orgánica para la reforma es "intensificar las garantías en la protección de los derechos de los ciudadanos". Y con esa finalidad, dice la misma Exposición de Motivos, que "la ley opta por reforzar el recurso de casación como instrumento por excelencia para asegurar la uniformidad en la aplicación judicial del derecho". Es decir, que el legislador ha querido fomentar en el recurso de casación la función uniformadora de la jurisprudencia, que no estaba bien construida anteriormente, pues conforme a la legislación anterior los asuntos quedaban excluidos de la casación no por su irrelevancia jurídica, sino por su cuantía. Ciertamente conviene a los ciudadanos una mayor uniformidad en la aplicación judicial del derecho, y esta es una función esencial de la casación de la que nadie duda, pues ello redunda en la seguridad jurídica y en la igualdad en la aplicación de la ley. Pero si el cauce por el cual se intenta lograr la uniformidad de la jurisprudencia (la reforma del recurso de casación) conlleva, al mismo tiempo, una mayor limitación de acceso a este recurso, habrá que cuestionar los resultados de la reforma ${ }^{6}$.

Aparentemente la reforma no limita el acceso a la casación, sino que lo amplía, pues no se restringe la admisión de los recursos en función de su cuantía. Los autos y las sentencias, con independencia de su cuantía, podrán ser recurridos en casación. Sin embargo, tras esa primera puerta revisora de la cuantía del asunto (que formalmente desaparece ahora) se crea otra, que posiblemente pocos conseguirán traspasar: la del interés casacional del asunto.

El recurso de casación contencioso-administrativo, que se creó en la Ley 10/1992, de 30 de abril, de Medidas Urgentes de Reforma Procesal (pues antes solo existía apelación ante el Tribunal Supremo), se ha configurado como un mecanismo para revisar la aplicación de la ley sustantiva y procesal por parte de los órganos judiciales. En esta línea ha dicho Bouazza Ariño que "el recurso de casación es el mecanismo contemplado por nuestro ordenamiento jurídico-procesal para la revisión de los criterios interpretativos empleados por los órganos jurisdiccionales en grado, y está dirigido exclusivamente a la determinación de la correcta interpretación y aplicación del Derecho"”.

El Tribunal Supremo ha subrayado el carácter unificador de jurisprudencia del

${ }_{6}$ Cfr. Exposición de Motivos de la Ley Orgánica 7/2015, de 21 de julio, por la que se modifica la Ley Orgánica 6/1985, de 1 de julio, del Poder Judicial.

7 BOUAZZA ARIÑO, O., El recurso de casación contencioso-administrativo común, Thomson Reuters Civitas, 2013, pág. 34 . 
recurso de casación al decir que “(...) tiene por objeto fundamental, no tanto analizar las pretensiones de las partes, como comprobar el proceder de los órganos judiciales de instancia; es decir, tiene como finalidad revisar la aplicación de la ley sustantiva y de la ley procesal, en aras de la tutela judicial efectiva". Y ha añadido que "(...) por medio de este extraordinario recurso de casación, el Estado atiende, también, a un fin público; proteger la norma y crear pautas interpretativas uniformes que presten la máxima seguridad jurídica conforme a las exigencias de un Estado de Derecho"9.

Por ello, se ha dicho que el Tribunal Supremo debía centrar sus esfuerzos en aquellos asuntos provechosos para asegurar la unidad del ordenamiento jurídico en su interpretación y aplicación ${ }^{10}$. Esa es la verdadera razón de la reforma, que tiene origen en la ya antigua queja de Magistrados/as del Tribunal Supremo sobre la masificación del recurso de casación, que además ha sido atendida por el legislador, que ha ido dando pasos poco a poco en esa línea mediante diversas reformas. Esta última reforma será probablemente la más efectiva para que el Tribunal Supremo seleccione e inadmita asuntos.

Lo lamentable, entre otras cosas, como veremos, es que la reforma no haya sido acompañada de una variación del esquema procesal mismo, pues muchos litigios seguirán viéndose en una sola instancia (los que se inicien ante Tribunales Superiores de Justicia y Audiencia Nacional; y la mayoría quedarán, además, sin posibilidad siquiera de casación. O sea, que se resolverán a una sola carta, lo que me parece una grave equivocación, que lo es además en detrimento de la protección judicial que impone nuestro Texto Constitucional, aunque el Tribunal Constitucional haya dicho que no se quebranta el derecho a la tutela judicial efectiva porque un proceso contencioso-administrativo concluya definitivamente en única instancia ${ }^{11}$. A mi juicio todo proceso

8 STS (Sala de lo Contencioso-Administrativo, Sección 2a), de 9 de octubre de 2014 (RJ 2014\5001).

9 STS (Sala de lo Contencioso-Administrativo, Sección 3a), de 31 de enero de 2001 (RJ 2001\4042).

10 QUINTANA CARRETERO, J.P., "El recurso de casación: exigencias formales y cuestiones de fondo como fundamento de la inadmisión del recurso de casación" en SIEIRA MIGUEZ, J.M. (dir.) y QUINTANA CARRETERA, J.P. (coord.), El recurso de casación en la jurisdicción contencioso-administrativa, Thomson Reuters Aranzadi, 2012, pág. 38

11 STC 37/1995: "El sistema de recursos se incorpora a la tutela judicial en la configuración que le dé cada una de las leyes de enjuiciamiento reguladoras de los diferentes órdenes jurisdiccionales, sin que ni siquiera exista un derecho constitucional a disponer de tales medios de impugnación, siendo imaginable, posible y real la eventualidad de que no existan, salvo en lo penal (STC 140/1985, 37/1988 y 106/1988). No puede encontrarse en la Constitución ninguna norma o principio que imponga la necesidad de una doble instancia o de unos determinados recursos, siendo posible en abstracto su inexistencia o condicionar su admisibilidad al cumplimiento de ciertos requisitos; que la regulación, en esta materia, pertenece al ámbito de libertad del legislador (STC 3/1983), que el principio hermenéutico "pro actione” no opera con igual intensidad en la fase inicial del proceso, para acceder al sistema judicial, que en las sucesivas, conseguida que fue una primera respuesta judicial a tal pretensión que es la sustancia medular de la tutela y su contenido esencial, sin importar que sea única o múltiple, según regulen las normas procesales el sistema de recursos y 
contencioso-administrativo, como sucede ante la jurisdicción ordinaria, debería iniciarse ante el Juzgado correspondiente.

Lo cierto es que las distintas modificaciones de ese recurso extraordinario (de casación) que se han ido produciendo desde 1992 hasta la fecha, han tenido siempre por objeto restringir el acceso al recurso y reducir el número de recursos que pudieran interponerse.

El legislador de 1998, al aprobar la vigente Ley Jurisdiccional, argumentaba que las cuantías fijadas por la Ley 10/1992 no habían permitido reducir la abrumadora carga de trabajo que pesaba sobre la Sala de lo Contencioso-Administrativo del Tribunal Supremo, y que era preciso elevar la cuantía de los recursos que podían tener acceso a la casación, pues de lo contrario se agravaría la situación más allá de lo razonable, y se correría el riesgo de alargar la resolución de los recursos hasta extremos totalmente incompatibles con el derecho a una justicia efectiva. Además, decía, sin explicación alguna, y como si no fuera posible otra alternativa, que no se podía aumentar el número de Secciones y Magistrados/as del Alto Tribunal, que tenía que atender su importantísima función objetiva de fijar la doctrina jurisprudencial. Con esta finalidad el legislador elevó la cuantía del recurso de 6.000.000 pesetas en la Ley 10/1992, a 25.000.000 en la LJCA de 1998, (ajustada posteriormente a 150.000 euros), y a 600.000 euros en la Ley 37/2011, de 10 de octubre, que modificó el apartado 2.b) del artículo 86 de la LJCA (en el proyecto de aquella ley la cuantía era 800.000 euros).

Ya señalé en otro trabajo, como lo han hecho otros autores, que el legislador viene restringiendo desde hace años el acceso a los tribunales a través de diferentes medidas, como si la restricción de acceso fuera la panacea para resolver la grave crisis que atraviesa desde hace mucho tiempo nuestra justicia: la elevación de la cuantía para la apelación y la casación, las muy criticables (e inconstitucionales) tasas judiciales ${ }^{12}$, o la introducción, entre otras medidas, de la especial trascendencia constitucional en el recurso de amparo, y del interés casacional en el recurso de casación ${ }^{13}$, invariablemente siempre reduciendo o eliminando el acceso a la tutela judicial del justiciable.

Una muestra más en ese camino fue la introducción, en el artículo 93.2.e) de la LJCA

que es distinto el enjuiciamiento que puedan recibir las normas obstaculizadoras o impeditivas del acceso a la jurisdicción o aquellas otras que limitan la admisibilidad de un recurso extraordinario contra una sentencia anterior dictada en un proceso celebrado con todas las garantías STC 3/1983 y 294/1994 (...)".

12 Que han sido anuladas en parte por la STC núm. 140/2016, de 21 de julio de 2016 (BOE núm. 196, de 15 de agosto de 2016).

13 RECUERDA GIRELA, M.A., "La necesaria reforma del régimen de recursos administrativos: los modelos del recurso extraordinario de revisión y del recurso especial en materia de contratación", Revista Española de Derecho Administrativo, núm. 159, 2013. 
de 1998, como causa de inadmisión del recurso, de la falta de interés casacional (que no contemplaba la Ley 10/1992). Esta causa se estableció para los asuntos de cuantía indeterminada que no se refirieran a la impugnación directa o indirecta de una disposición general, si el recurso estaba fundado en el motivo del artículo 88.1.d), y que se apreciara la carencia de interés casacional por no afectar a un gran número de situaciones o no poseer el suficiente contenido de generalidad ${ }^{14}$. Tal motivo de inadmisión de casaciones, que en un primer momento fue aplicado por la Sala de lo Contencioso-Administrativo del Tribunal Supremo con gran prudencia, para evitar lesionar el derecho a la tutela judicial efectiva, se ha venido aplicando con mayor intensidad desde hace unos años ${ }^{15}$, y no ha suscitado reparos del Tribunal Constitucional, auténtico experto en inadmitir amparos por carencia de relevancia constitucional de las impugnaciones, pues inadmite cerca del 99 por ciento de las demandas, lo que sencillamente es inaudito ${ }^{16}$. Sorprende que se sigan interponiendo tantos recursos de amparo inviables a la vista de los criterios tan restrictivos del Tribunal Constitucional.

El legislador no ha estado sólo en esa tarea de limitar el acceso a la casación, sino que ha contado con el Tribunal Supremo, que se ha esmerado en perfilar motivos de inadmisión de casaciones, por ejemplo, a base de imponer exigencias formales a los mismos.

Convirtió así (de nuevo con la abierta anuencia del Tribunal Constitucional) la preparación de las casaciones en verdaderos escritos de interposición, confundiendo la necesidad de expresar el cumplimiento de las formalidades para su admisión con, incluso, la obligatoriedad de indicar y hasta fundamentar cuáles serán los motivos de casación mismos.

Otro ejemplo más llamativo aun: el atribuir a sentencias de TSJ dictadas en única instancia (en procesos iniciados cuando aún no había Juzgados de lo Contencioso) naturaleza de sentencias de apelación a efectos de impedir recursos de casación contra ellas, aduciendo que, de haber existido Juzgados cuando se iniciaron esos procesos, los asuntos habrían sido conocidos por ellos en instancia. Me parece verdaderamente

\footnotetext{
14 Sobre la inadmisión vid. MONTOYA MARTÍN, E., El recurso de casación contencioso-administrativo: en especial las causas de inadmisibilidad, MC Graw Hill, 1997.

15 Son ilustrativos los fundamentos que el Tribunal Supremo ha venido invocando para inadmitir recursos conforme al artículo 93.2.e). Así, por ejemplo, el ATS de 18 de junio de 2015 (recurso 3341/2014) aprecia la falta de interés casacional en un conflicto marcario porque: (i) en el recurso de casación no se plantea ninguna cuestión dotada de un contenido de generalidad y entidad jurídica tal que justifique su examen por el Tribunal Supremo, sino que, al contrario, se trata de una cuestión de carácter marcadamente casuístico y perfiles singulares; y, (ii) no se plantea en el recurso de casación ninguna cuestión interpretativa y aplicativa de normas jurídicas, en torno a la cual se revele necesario el examen y respuesta del TS.

16 AATS (Sala de lo Contencioso-Administrativo, Sección 1 ${ }^{\mathrm{a}}$ ), de 28 de octubre de 2010 (RC 3287 /2009), de 7 de abril de 2011 (RC 3658/2010), y de 7 de abril de 2011 (RC 4768/2009). Vid. Memoria del Tribunal Constitucional de 2014.
} 
inaudita semejante interpretación (basada en la pura hipótesis), y siempre en la línea contraria a la admisión de los recursos de casación.

Hay más ejemplos, pero solo añadiré el de la cuantía, por el que se divide todo lo posible (factura por factura, multa por multa o participación por participación) de forma que el recurrente no alcanza el importe mínimo que hasta ahora ha dado acceso a las casaciones. Se han dado casos, por ejemplo, de dos expropiados copropietarios de un inmueble al 75\% y 25\% en los que solo se ha admitido la casación de uno de ellos (el de mayor participación, a la misma suficiente para alcanzar la cifra), y hasta se ha acabado estimando su recurso y subiendo a ese copropietario el justiprecio ante su demudado hermano, a quien nadie es capaz de explicar hasta qué irracionalidad llegamos los juristas cuando nos empeñamos.

El deseo (de los Magistrados/as del Tribunal Supremo, que no de la "Justicia", entiendo) de limitar el acceso a la casación se ha manifestado expresamente públicamente en varias ocasiones, y buenas muestras de ello son la "Exposición razonada, relativa al proyecto de Ley Orgánica que modifica la Ley Reguladora de la Jurisdicción Contencioso-administrativa y reforma del recurso de casación" de 31 de octubre de 2006, y el "Informe de la Sala de Gobierno del Tribunal Supremo sobre el anteproyecto de 4 de abril de 2014 de la LOPJ". En ambos casos se ha sugerido un modelo de recurso de casación en el que el Tribunal Supremo pudiera admitirlo a trámite cuando estimara libremente que el mismo merece la pena (el llamado interés casacional). Conste, no obstante, que, al menos desde Cappelletti, algunos autores han señalado que la medida más sencilla para reducir el volumen de trabajo del Tribunal Supremo es la concesión a éste de la potestad de elegir los asuntos sobre los que pronunciarse.

Pero ni la masificación del recurso de casación contencioso-administrativo, ni la imposibilidad de aumentar medios humanos y materiales en el Tribunal Supremo, son suficientes para justificar las reformas, y menos la última; el motivo está en la errónea voluntad de cambiar de modelo. En los últimos años ha sido posible adoptar medidas de refuerzo del Gabinete Técnico del Tribunal Supremo, se ha reducido muy significativamente la cifra de recursos de casación pendientes de admisión (trámite que en la actualidad se cumple en unos tres meses de promedio), y se ha reducido el número de recursos pendientes de resolución (con un plazo medio de un año) ${ }^{17}$. Cuestión dis-

17 En relación con los resultados del plan de refuerzo vid. QUINTANA CARRETERO, J.P., op.cit., pág. 41: "Los resultados del plan de refuerzo han sido altamente satisfactorios, tal y como ponen de manifiesto las estadísticas del Tribunal publicadas anualmente, pues la cifra de recursos de casación pendientes de admisión se ha reducido desde unos 16.000 recursos existentes en el año 2005 hasta los poco más de 2.000 recursos en el mes de julio de 2013, lo que ha conducido a que un trámite como este que tardaba en 
tinta es si esas medidas de refuerzo pueden sostenerse económicamente en el tiempo, si los recursos económicos pueden emplearse de forma más eficiente para mejorar la justicia administrativa, y si el elegido es el modelo más adecuado. Esperaremos a ver qué sucede ahora.

\section{LA ENTRADA EN VIGOR DE LA REFORMA}

La reforma del recurso de casación contencioso-administrativo ha entrado en vigor el 22 de julio de 2016, según la escueta disposición final décima de la Ley Orgánica $7 / 2015$, después de un plazo amplio de vacatio legis ${ }^{18}$.

La redacción (más bien el silencio absoluto) de la disposición final décima de la Ley Orgánica 7/2015 es imprecisa, por lo permite al menos tres interpretaciones respecto a las resoluciones que son recurribles en casación:

(i) serán recurribles en casación, conforme a los requisitos del nuevo recurso, las sentencias y autos que se hayan notificado a partir del 22 de julio de 2016;

(ii) las sentencias y autos dictados a partir de dicha fecha; $y$,

(iii) las sentencias y autos que estén en plazo de recurso de casación en esa fecha.

Dado que la Ley no contiene una disposición transitoria específica, y por virtud del principio pro actione, entiendo que deberían ser susceptibles del nuevo recurso de casación las sentencias y autos que estén en plazo de recurso el 22 de julio de 2016. No obstante, el mismo 22 de julio de 2016, la Sección de Admisión de la Sala Tercera del Tribunal Supremo aprobó (sin competencia para ello, y en todo caso en contra de la Ley Orgánica 7/2015) unos llamados "Criterios de entrada en vigor de la nueva casación”, entre los que se indica que la nueva regulación casacional se aplica a las

cumplimentarse varios años se concluya en la actualidad en unos tres meses por término medio. Por lo que respecta a la cifra de recursos de casación que, superado el trámite de admisión se encuentran pendientes de resolución definitiva mediante sentencia, desde marzo de 2011 se ha visto reducida en más de 5.000 recursos, lo que supone casi la mitad de la cifra de pendencia, pudiéndose aventurar que de mantenerse las medidas de refuerzo implantadas desde marzo de 2011 y durante este año 2012 se alcanzaría a finales del presente año la plena actualización de la Sala, entendiendo por ello que los recursos de casación se resolverían por término medio en el plazo de un año".

18 Los plazos amplios de vatio legis no son lo más habitual. Sin embargo, tampoco son excepcionales. Algunos ejemplos recientes de ello son: la Ley 39/2015, 1 de octubre, de Procedimiento Administrativo Común de las Administraciones Públicas, la Ley 40/2015, de 1 de octubre, de Régimen Jurídico del Sector Público, la Ley 15/2015, de 2 de julio, de la Jurisdicción Voluntaria, la Ley 24/2015, de 24 de julio, de Patentes o la Ley 22/2015, de 20 de julio, de Auditoría de Cuentas. 
sentencias y autos susceptibles de recurso de casación que tengan fecha 22 de julio de 2016 en adelante, y que las resoluciones que tengan fecha anterior, con independencia de cuando se notifiquen, se regirán por la legislación anterior.

En ese acuerdo, el Tribunal Supremo considera que en caso de aclaración o integración de sentencias y autos conforme al artículo 267 de la Ley Orgánica 6/1985, de 1 de julio, del Poder Judicial, el plazo para recurrir se computará desde la notificación de la resolución por la que se aclare o complemente. Sin embargo, aunque la aclaración o complemento sea posterior al 22 de julio, lo determinante para la aplicación de la nueva casación será la fecha de la sentencia o auto, que tendrá que ser posterior a dicha fecha. Cuestión distinta sería, el caso de un Auto que declarase la nulidad de una resolución anterior conforme a los artículos 228 de la LEG y 241 de la LOPJ.

El criterio del Tribunal Supremo no es correcto; incluso desvirtúa el derecho fundamental al juez ordinario predeterminado por la ley (art. 24.2 CE) ${ }^{19}$ al hacer depender el mismo de la fecha en la que se dicte la resolución, y, por tanto, de la voluntad del órgano judicial, la recurribilidad en casación.

\section{LA SUPRESIÓN DEL REGURSO DE CASACIÓN PARA LA UNIFICACIÓN DE LA DOGTRINA Y DEL REGURSO DE CASACIÓN EN INTERÉS DE LEY}

La LJCA contempló un régimen enmarañado hasta el límite, bajo tres modalidades de recurso de casación contencioso-administrativo:

(i) el recurso de casación común (arts. 86 a 95), que algunos denominan ordinario (aunque el recurso de casación es en sí mismo un recurso extraordinario);

(ii) el recurso de casación para la unificación de la doctrina (arts. 96 a 99); y,

(iii) el recurso de casación en interés de la ley (arts. 100 y 101).

A ello había que añadir modalidades estatales y autonómicas de los recursos de casación.

La Ley Orgánica 7/2015 ha suprimido los recursos de casación en interés de ley y

19 Sobre el juez ordinario predeterminado por la ley, aunque no trata específicamente este supuesto concreto," cfr. SERRANO ALBERCA, J.M., y ARNALDO ALCUBILLA, E., "Artículo 24", en GARRIDO FALLA, F., Comentarios a la Constitución, Civitas, 2001, pág. 548. 
para la unificación de doctrina, por lo que la casación contencioso-administrativa se ha reducido y simplificado a la modalidad común.

Por otra parte, el recurso de casación para la unificación de doctrina cabía contra sentencias dictadas en única instancia por las Salas de lo Contencioso-Administrativo del Tribunal Supremo, Audiencia Nacional y Tribunales Superiores de Justicia cuando, respecto a los mismos litigantes u otros diferentes en idéntica situación y, en mérito a hechos, fundamentos y pretensiones sustancialmente iguales, se hubieran dictado sentencias en sentido distinto; también cabía contra las sentencias de la Audiencia Nacional y de los Tribunales Superiores de Justicia dictadas en única instancia cuando la contradicción se produjera con sentencias del Tribunal Supremo en las mismas circunstancias señaladas anteriormente. Pero sólo eran recurribles en casación para la unificación de doctrina las sentencias que no lo fueran en casación ordinaria, y siempre que la cuantía litigiosa fuera superior a 30.000 euros. Este recurso era subsidiario de la casación común, por lo que no podía interponerse si era susceptible de éste. Su finalidad no era corregir las infracciones de las normas, sino reconducir a la unidad los criterios interpretativos de las Salas de lo Contencioso-Administrativo. Para que se apreciara la falta de unidad entre las resoluciones firmes de contraste ${ }^{20}$ y la recurrida, y se casase ésta, era preciso que existiera, y que se expresara razonadamente con precisión y concreción, la triple identidad de sujetos, fundamentos jurídicos, y pretensiones, de modo que se pudiera verificar el juicio de contradicción y determinar el criterio correcto. La sentencia que se dictara en esta modalidad de casación se limitaba al asunto objeto del recurso.

El recurso de casación en interés de la ley (clásico en Derecho Administrativo, a diferencia del anterior, que fue una novedad de la Ley 10/1992), procedía contra las sentencias dictadas en única instancia por los Jueces de lo Contencioso-Administrativo, así como contra las pronunciadas por las Salas de lo Contencioso-administrativo de los Tribunales Superiores de Justicia y de la Audiencia Nacional que no fueran susceptibles de los recursos de casación común ni para unificación de doctrina, cuando la sentencia fuera errónea o disparatada ${ }^{21}$ y gravemente dañosa para el interés general (cuestiones

20 Se debía acompañar certificación con mención de su firmeza o, en su caso, copia simple de las mismas y escrito justificante de haberla solicitado, pues lo exigía el art. 97.2 LJCA, y, si se omitía, era un defecto insubsanable (STS (Sala de lo Contencioso-administrativo, Sección 4 ${ }^{\mathrm{a}}$ ), de 5 de noviembre de 2009 [RJ 2009\7954]). El escrito de solicitud de justificante convenía solicitarlo antes de la interposición del recurso y además con petición expresa de mención de la firmeza de las sentencias.

21 Sobre el concepto de error judicial vid. STS (Sala de lo Contencioso-administrativo, Sección $2^{\mathrm{a}}$ ) de 12 de abril de 2002 (RJ 2002\362): "Así como, por una parte, el error judicial ha de ser patente, advertible inmediatamente, grosero, etc., es decir -cabría calificar en lenguaje vulgar- que ha de representar una solución disparatada y por la otra parte, la inadecuación a derecho que da lugar a la casación ordinaria o en unificación de doctrina de una Sentencia, es la oposición entre el ordenamiento Furídico y lo la Furisprudencia y la fundamentación y fallo de la resolución judicial impugnada, la «doctrina erróneà está entre ambos conceptos, siendo una interpretación jurídica que, además de incurrir en vulneración de normas legales 
ambas que obviamente había que acreditar), y solo podían interponerlo las Entidades o Corporaciones que ostentasen la representación y defensa de intereses de carácter general o corporativo y tuviesen interés legítimo en el asunto, el Ministerio Fiscal y la Administración General del Estado. La sentencia dictada con motivo de un recurso de casación para la unificación de la doctrina tenía efectos respecto del futuro, pero debía respetar la situación jurídica particular. Distintos autores se han pronunciado anteriormente sobre la desacertada regulación del recurso de casación en interés de ley ${ }^{22}$.

La supresión de esas dos modalidades de casación sería un acierto si el nuevo recurso de casación único abarcara los remedios a los que debían servir esos otros recursos, lo que no sucede ${ }^{23}$ ni en cuanto a motivos de impugnación (en especial cuando se trate de unificar doctrina del propio Tribunal Supremo ${ }^{24}$ ), ni en cuanto a que la nueva casación pasa a ser de admisión discrecional y, por ende, de utilidad discutible para quien pretende ser impugnante, que no sabe si dispone o no de acción (en contra de lo que debe ser esencia del derecho procesal, que es la seguridad en cuanto a las acciones de que dispone).

\section{EL OBJETO DEL REGURSO DE GASAGIÓN}

La reforma operada por la Ley Orgánica 7/2015 ha ampliado el objeto del recur-

concretas, lo haga de manera patente, no razonada o dificilmente razonable, que exige una rectificación esclarecedora para el futuro.

Hasta tal punto es ésta la finalidad de dicha clase singular, excepcional y subsidiaria de recurso de casación, que si la doctrina correcta, es decir, la interpretación acertada, está ya declarada en Sentencia dictada en otro recurso de la misma naturaleza, o en reiterada furisprudencia, no ha lugar a reiterarla, dado que la situación particular declarada por el fallo erróneo queda, en todo caso, intacta.

A la luz de estos principios y como ha puesto de manifiesto el Ministerio Fiscal en su informe, ambas interpretaciones, tanto la sostenida por la Sentencia recurrida, como la postulada por el Ayuntamiento recurrente, son sostenibles dentro de los límites razonables del criterio humano, sin que deba optarse aqui para no desnaturalizar la casación en interés de la Ley que, significativamente exige, para la fijación de la doctrina legal, además del carácter erróneo de la sostenida por la Sala de instancia, que sea gravemente perjudicial para el interés general, lo que tampoco puede reducirse a cualquier previsible disminución de la recaudación tributaria, en estos casos, si no que exige la justificada posibilidad de lesión del conjunto de valores que integran el concepto social de bien común".

22 BLANQUER CRIADO, D., "El llamado recurso en interés de ley: la legitimación y su fundamento extraprocesal; la postulación", Revista de Administración Pública, núm. 130; DOMÉNECH PASCUAL, G., "Creación judicial del Derecho a través del recurso de casación en interés de la ley", InDret, 1/2013.

23 En sentido contrario LOZANO CUTANDA, B., "La reforma del recurso de casación contenciosoadministrativo por la Ley Orgánica 7/1985: análisis de novedades”, Diario La Ley, núm. 8599, de 7 de septiembre de 2016.

24 Téngase en cuenta que en el Alto Tribunal también se generan disparidades de criterio, aunque resulte sorprendente. A este respecto sostiene FERNÁNDEZ FARRERES que “(...) no deja de ser arriesgado dar por supuesto que la uniformidad jurisprudencial se observará en el seno de diversas Secciones de la Sala Tercera (...)" (FERNÁNDEZ FARRERES, G., "Sobre la eficiencia de la jurisdicción contencioso-administrativa y el nuevo recurso de casación para la formación de jurisprudencia", Revista Española de Derecho Administrativo, núm. 174, 2015). 
so de casación a las sentencias de los Juzgados de lo Contencioso-Administrativo, aunque, como se ha señalado anteriormente, ha suprimido la casación para la unificación de doctrina, con lo que se impide por esta vía el recurso contra sentencias del propio Tribunal Supremo. Por tanto, podrán ser objeto de recurso de casación:

(i) Las sentencias dictadas en única instancia por los Juzgados de lo Contencioso-Administrativo (Juzgados y Juzgados Centrales, aunque la ley se refiera expresamente, por olvido, solo a los primeros). No obstante, la aparente apertura de la casación a sentencias de Juzgados (que anteriormente era posible sólo a través del recurso de casación en interés de ley) se torna en una realidad muy limitada, pues las sentencias de los Juzgados solo serán recurribles en casación cuando contengan doctrina que se repute gravemente dañosa para los intereses generales y sean susceptibles de extensión de efectos. Será la Sala del Tribunal Supremo la que tendrá que valorar si las sentencias contienen o no doctrina gravemente dañosa para el interés general, lo que constituye un concepto jurídico indeterminado que solo se reconocerá, probablemente, en supuestos muy excepcionales. El Tribunal Supremo ya ha interpretado esas dos circunstancias, por lo que hay doctrina sobre ello, aunque habrá que esperar a las primeras resoluciones para saber si mantendrá o no sus criterios anteriores;

(ii) Las sentencias dictadas en apelación por la Sala de lo Contencioso-Administrativo de la Audiencia Nacional, (que no eran recurribles) además de las dictadas en única instancia por la propia Sala (éstas ya eran susceptibles de recurso de casación); y,

(iii) Las sentencias dictadas en apelación por las Salas de lo Contencioso-Administrativo de los Tribunales Superiores de Justicia, (que no eran recurribles) además de las dictadas en única instancia por ellas (que también eran ya recurribles en casación antes de la reforma).

Se ha eliminado el criterio de la summa gravaminis para el acceso a la casación (que fuera superior a 600.000 euros como se exigía anteriormente), excepto en los procedimientos de protección de derechos fundamentales. Por tanto, tras la reforma, la recurribilidad de la resolución judicial ya no depende de la cuantía del recurso, sino del llamado interés casacional objetivo para la formación de la jurisprudencia, que, al ser otro concepto jurídico indeterminado que tiene que ser precisado por el Tribunal Supremo en cada caso, genera una gran incertidumbre en los recurrentes sobre la previsibilidad de la admisión del recurso. Por ello, será muy importante ir conociendo las resoluciones del Tribunal Supremo en este sentido, que previsiblemente puede acabar convirtiéndose en un tamiz similar al que opera en nuestro ordenamiento para la inadmisión de demandas de amparo constitucional -aunque espero que no sea así por el bien de la Justicia-. 
El criterio de la cuantía, que como se ha visto, ha sido determinante de la progresiva limitación de acceso a la casación, objetiviza la admisión del recurso, aunque no toma en consideración la relevancia jurídica ni social de cada asunto.

Con la reforma se han reducido las excepciones al recurso de casación contempladas en el artículo 86 de la LJCA (es decir las sentencias que no pueden ser recurridas en casación), que quedan limitadas a las sentencias dictadas en el procedimiento para la protección del derecho fundamental de reunión, y a las relativas a procesos contencioso-electorales (anteriormente se excluían también las recaídas, cualquiera que fuera la materia, en asuntos que no excedieran de 600.000 euros, excepto cuando se tratara del procedimiento especial para la defensa de los derechos fundamentales, en cuyo caso procedería el recurso cualquiera que fuera la cuantía del asunto, y las sentencias que se refirieran a cuestiones de personal al servicio de las Administraciones públicas, salvo que afectasen al nacimiento o a la extinción de la relación de servicios de funcionarios de carrera). A este respecto, Fernandez Farreres ha criticado que la función nomofiláctica del recurso de casación no alcance a la doctrina fijada sobre el derecho de reunión (incluir aquí la nota 25). No veo obstáculo para que en una futura reforma se incluyan esas materias excluidas en el ámbito del recurso de casación, con las modificaciones que sean precisas para una tramitación urgente y rápida de los recursos, ahora además que el Alto Tribunal podrá reducir el número de recursos.

Se mantiene igual el recurso contra las sentencias dictadas por las Salas de lo Contencioso-Administrativo de los Tribunales Superiores de Justicia que sean susceptibles de casación, que sólo serán recurribles ante la Sala de lo Contencioso-Administrativo del Tribunal Supremo cuando el recurso pretenda fundarse en la violación de normas de Derecho estatal, o de la Unión Europea que hayan sido relevantes y determinantes del fallo. Hay sin embargo una diferencia de redacción en tal exigencia que puede ser relevante. Antes se exigía que esas normas "hubieran sido invocadas oportunamente en el proceso o consideradas por la Sala sentenciadora", mientras que ahora, aunque el art. 86.3 lo repite, el art. 89 hace referencia a si "la norma supuestamente infringida forma parte del Derecho estatal o del de la Unión Europea", y a que basta que se trate de norma "tomada en consideración por la Sala de instancia, o que ésta hubiera debido observarlas aun sin ser alegadas". Por tanto, basta su infracción (aunque no haya sido propiamente objeto de debate) para que quepa recurso de casación. Me parece correcta la reforma en este punto ya que muchas veces, por ejemplo, la cita o consideración de una norma en una resolución judicial es novedosa y hasta sorprendente para los litigantes.

Si el recurso de casación se funda en infracción de normas de la Comunidad Autónoma, la competencia para conocer del mismo será de una Sección de la Sala de 
lo Contencioso-Administrativo que tenga su sede en el Tribunal Superior de Justicia - antes de la reforma esto solo era posible en recursos de casación para unificación de doctrina-, pues el legislador ha querido que haya un recurso de casación (común, pues ya se ha dicho que ha desaparecido el de unificación de doctrina) que sirva para que el último interprete judicial de la legislación autonómica sea el correspondiente Tribunal Superior de Justicia. Este requisito también ha suscitado en la práctica situaciones controvertidas, que la reforma no soluciona como debiera; así sucede cuando el recurso se fundamenta tanto en la infracción de derecho estatal o de la Unión Europea como en derecho autonómico - se llega incluso a ponderar el peso de uno y otro en la fundamentación o a atribuir al derecho estatal un valor instrumental en algún caso- . Esto sucede, por ejemplo, cuando en el recurso se invocan principios constitucionales - como la jerarquía normativa- o normas del procedimiento administrativo común como el art. 47.2 de la Ley 39/2015 25 en asuntos en los que el derecho autonómico, y no el estatal, es realmente esencial para su resolución ${ }^{26}$.

(iv) No se ha modificado por la Ley Orgánica 7/2015 el régimen de recurribilidad de las resoluciones del Tribunal de Cuentas en materia de responsabilidad contable conforme a su Ley de Funcionamiento.

(v) Aunque aparentemente no se ha alterado significativamente el régimen del recurso de casación contra autos, su deficiente regulación planteará algunas dudas, pues el artículo 87.1 no explicita si solo son susceptibles de recurso de casación los autos dictados en instancia por la Sala de lo Contencioso-Administrativo de la Audiencia Nacional y por las Salas de lo Contencioso-Administrativo de los Tribunales Superiores de Justicia, o si también son recurribles en casación los autos dictados en

25 Sobre la Ley 39/2015 y la Ley 40/2015 puede consultarse, entre otras obras, RECUERDA GIRELA, M.A. (dir.), Régimen Furídico del Sector Público y Procedimiento Administrativo Común, Thomson Reuters Aranzadi, 2016.

26 STS (Sala de lo Contencioso-administrativo, Sección 5 ${ }^{\text {a) }}$, de 15 de febrero de 2012 (RJ 2012\4018): "Debemos reparar que si bien los principios constitucionales, principios generales del derecho, y los de procedimiento administrativo, resultan de aplicación a todos los ordenamientos jurídicos, tanto el estatal como los autonómicos, y con carácter general a todos los ámbitos sectoriales del Derecho, su proyección, según el caso, se concreta en las diferentes normas autonómicas, de cuya aplicación e interpretación no puede prescindirse a los efectos de examinar tales infracciones. De modo que es una norma autonómica la que define, ahora en el ámbito urbanístico, la distribución de competencias en materia de protección de la legalidad urbanística entre la Administración de la Comunidad Autónoma, cuya interpretación resulta imprescindible para analizar la infracción denunciada. En este sentido, se viene pronunciando esta Sala, sobre la infracción de los principios del artículo 9.3 y la nulidad del artículo 62 de la LRZPA, al señalar que "Estos preceptos, en cuento tienen el carácter de instrumentales, y, por tanto, constituyen elementos comunes para todos los ordenamientos jurídicos, ya sea el estatal, autonómico o local, no pueden servir de base por si solos para fundar un recurso de casación, cuando el derecho material es puramente autonómico. pues admitir lo contrario sería tanto como privar de contenido al artículo 86.4 de la Ley Jurisdiccional, al existir siempre la posibilidad de acogerse a estos preceptos instrumentales y principios generales para con base en su infracción entablar el recurso de casación" (STS de 17 de septiembre de 2008 (R7 2008, 6160), RC 4118 / 2005 y de 14 de octubre de 2011 (fUR 2011, 373317), RC 5992/2007)". 
apelación. Lo que sí parece más claro es que no cabe casación contra los autos de los órganos judiciales unipersonales. Conforme al artículo 87.1 podrá interponerse recurso de casación contra los siguientes autos: a) Los que declaren la inadmisión del recurso contencioso-administrativo o hagan imposible su continuación; b) Los que pongan término a la pieza separada de suspensión o de otras medidas cautelares; c) Los recaídos en ejecución de sentencia, siempre que resuelvan cuestiones no decididas, directa o indirectamente, en aquélla o que contradigan los términos del fallo que se ejecuta; d) Los dictados en el caso previsto en el artículo 91 (ejecución provisional de sentencia); y, e) Los dictados en aplicación de los artículos 110 y 111 (extensión de efectos de sentencias).

En todo caso, antes de la preparación del recurso de casación contra autos, es necesaria la interposición de recurso de reposición, al que la Ley Orgánica 7/2015 denomina por error recurso de súplica ${ }^{27}$. Ya quedó aclarado por la jurisprudencia que el recurso de casación se podía dirigir contra el auto que resolviera el recurso o contra el dictado inicialmente, objeto de éste ${ }^{28}$.

\section{EL ACGESO A LA GASACIÓN: EL INTERÉS CASACIONAL OBJETIVO PARA LA FORMACIÓN DE LA JURISPRUDEN- CIA}

La LJCA configuraba el recurso de casación como un recurso extraordinario (que solo podía interponerse frente a determinadas resoluciones judiciales y que se fundamentaba en motivos precisos ajenos, en principio, a cuestiones de hecho), no como una segunda o tercera instancia ${ }^{29}$, y lo articulaba sobre la base de un sistema de motivos tasados que se regulaban en el artículo 88.1 de dicha Ley. El arraigo del sistema de motivos tasados, que ahora se ha suprimido en su formalidad ${ }^{30}$ (en todo caso no deben referirse a cuestiones de hecho, como establece el nuevo art. 87.bis.1), llevó al profesor

27 Como ha observado acertadamente BLANCA LOZANO, la Ley 13/2009, de reforma de la legislación procesal para la implantación de la oficina judicial cambió la denominación del "recurso de súplica" por la de "recurso de reposición", lo que sorprendentemente no ha advertido el legislador (LOZANO CUTANDA, B., op.cit.).

28 STS (Sala de lo Contencioso-administrativo, Sección 5 $5^{\mathrm{a}}$ ), de 11 de noviembre de 2011 (RJ 2012\2136).

29 SANTAMARÍA PASTOR, J.A., Principios de Derecho Administrativo General II, Iustel, Madrid, 2015, pág. 808.

30 Es de agradecer ante la inseguridad que generaba. De hecho, en determinados casos nunca estuvo claro si la vía adecuada era la del apartado c) o la del apartado d) art. 88.1, a lo que se añade el sorprendente rechazo (una muestra más contra la admisión de casaciones) de los recursos en los que una y otra se planteaban de forma sucesiva y supletoria (el Derecho no es matemáticas, aunque se pretenda). 
González Pérez a afirmar que la casación española era un recurso que había venido definiéndose por dos notas esenciales: (i) que tenía que fundarse en causas o motivos extraordinarios, y (ii) que tenía que ser resuelta por el órgano superior de la jerarquía judicial $^{31}$.

El recurrente tenía la carga procesal de aducir de forma explícita, precisa y concreta el motivo o los motivos en los que se fundamentara el recurso. Y el debate quedaba limitado, tanto para el recurrente como para el recurrido, a esos motivos tasados, precisamente por el carácter extraordinario del recurso de casación. Por tanto, si concurría alguno de los motivos tasados, el recurso debía admitirse.

En la redacción previa a la última reforma poco importaba el interés del asunto desde una perspectiva general, al margen del propio interés que ostentara el recurrente (más allá del interés casacional indefinido previsto para litigios de cuantía indeterminada), como señala el magistrado Córdoba Castroverde, por lo que no era necesario justificar si el pronunciamiento era o no útil para la sociedad y para la comunidad jurídica, pues para acceder a la casación bastaba con cumplir los presupuestos objetivos $^{32}$.

Este sistema de control de acceso a la casación contencioso-administrativa se ha sustituido por un modelo que se fundamenta en la apreciación por el Tribunal Supremo del interés casacional (que no se define) objetivo para la formación de la jurisprudencia (o cuando se da alguno de los casos de trascendencia que refiere el nuevo art. 88.2) junto a la concurrencia de una concreta infracción del Ordenamiento Jurídico, tanto de carácter procesal como sustantiva, como de la jurisprudencia. Parece una contradicción que se refiera la Ley Orgánica 7/2015 al interés casacional objetivo, cuando en realidad la apreciación de ese interés es subjetiva, pues depende fundamentalmente del criterio de los Magistrados del Tribunal Supremo. Cuestión distinta es que el interés casacional tenga carácter objetivo en cuanto que su finalidad sea la interpretación unitaria de un Ordenamiento objetivo de una comunidad, y no la protección de derechos subjetivos.

Si el recurso de casación pende ahora del interés casacional, es obvio que prevalecerá la función nomofiláctica sobre la tutela de derechos, a pesar de que la Exposición de Motivos de la Ley diga que con "la finalidad de intensificar las garantías en la protección de los derechos de los ciudadanos, la ley opta por reforzar el recurso de casación como instrumento por excelencia para asegurar la uniformidad en la aplicación del derecho"; aunque es cierto que el reforzamiento de la función unificadora

31 GONZÁlEZ PÉREZ, J., Manual de Derecho Procesal Administrativo, Civitas, Madrid, 2001, pág. 623.

32 CÓRDOBA CASTROVERDE, D., "El nuevo recurso contencioso-administrativo", Revista de Furisprudencia, 1 de octubre de 2015. 
del recurso puede generar una mejor protección de la igualdad y de la seguridad jurídica. Con esta reforma, el Tribunal Supremo tendrá que decidir previamente sobre qué asuntos va a fallar ("deciding to decide", dicen los norteamericanos en relación con su Tribunal Supremo). Por ello, el litigante no sabrá nunca con cierta seguridad de qué acciones dispone, de modo que el recurso puede convertirse, mal aplicado, en una suerte de concesión cuasigraciable del Tribunal sentenciador, lo que sería inadmisible.

La simple alegación por el recurrente de la existencia de interés casacional no conllevará la necesaria admisión del recurso, a diferencia de lo que sucedía anteriormente cuando concurría un motivo del artículo 88.1, sino que la admisión dependerá del criterio de los Magistrados del Tribunal Supremo. Como ya dije, este modelo de recurso se inspira en el concepto de la "especial trascendencia constitucional" 33 , que permite al Tribunal Constitucional inadmitir la mayor parte de los recursos que se interponen por falta de esa trascendencia, y, también, de alguna forma, en el writ of certiorari del Tribunal Supremo de los Estados Unidos ${ }^{34}$, -aunque los modelos no son comparables-. El writ of certiorari es el medio para pedir al Tribunal Supremo norteamericano la revisión de una decisión de un tribunal inferior. Cada año se presentan en el Tribunal Supremo de los Estados Unidos más de 10.000 peticiones, y los nueve Jueces del Tribunal Supremo y sus law clerks dedican un importante esfuerzo a seleccionar las que deben ser revisadas, que no suelen ser más de 80. Los criterios de selección que emplea son:

(i) que el asunto tenga relevancia nacional;

(ii) que convenga armonizar las resoluciones de los federal circuit courts; o,

(iii) que se cree un precedente.

Como regla general, para que el Tribunal Supremo de los Estados Unidos admita un asunto, cuatro de los nueve jueces deben votar a favor. El writ of certiorari suele ser una incógnita porque su contenido no se conoce generalmente, salvo que un Juez decida abrir la caja y emitir una declaración motivada más o menos extensa. El Juez del Tribunal Supremo de los Estados Unidos, a través de su statement, puede disentir de la denegación

33 Sobre la especial trascendencia constitucional vid. STG (Sala Pleno), núm. 155/2009, de 25 de junio (RTC 2009\155). Vid. FABEIRO FIDALGO, F., "El nuevo recurso de amparo constitucional", Revista Vasca de Administración Pública, núm. 102, 2015.

34 Vid. PERRY, W.H., Deciding to decide: agenda setting in the United States Supreme Court, 1991. En español puede verse PÉREZ ALONSO, J., "El nuevo sistema de casación en el orden contencioso-administrativo operado por la Ley Orgánica 7/2015 de 21 de julio: con la vista puesta en el certiorari estadounidense", Diario La Ley, núm. 8621, 8 de octubre de 2015. 
del certiorari, mediante la explicación de las razones por las que debería haberse admitido el recurso, o puede aceptar la denegación del certiorari, con la explicación de los motivos concurrentes para la misma ${ }^{35}$. Por obvias razones, que escapan del alcance de este artículo, no es comparable el Tribunal Supremo de los Estados Unidos con el Tribunal Supremo del Reino de España, entre otras cosas, porque éste no es un tribunal constitucional, aunque se haya buscado cierta inspiración norteamericana en la reforma.

Sin embargo, a mi juicio, lo más grave de nuestra norma es que ese sistema puede operar sobre resoluciones dictadas en única instancia.

La Ley Orgánica 7/2015 se refiere, como llave de acceso a la casación, al interés casacional objetivo para la formación de la jurisprudencia. En realidad, la admisión del recurso tiene ahora un elemento subjetivo, pues su apreciación dependerá esencialmente de la valoración que hagan los Magistrados del Tribunal Supremo de cada caso $^{36}$, pues el interés casacional objetivo es un concepto jurídico indeterminado de libre apreciación (art. 88.2) ${ }^{37}$. Este modelo dota al Tribunal Supremo de un amplísimo margen de apreciación que le permitirá seleccionar los asuntos que accedan a la casación según su criterio sobre lo que deba o no ser revisado conforme a la regla del interés casacional.

Corresponderá inicialmente al recurrente justificar cumplidamente la existencia del interés casacional en su escrito de preparación, pues de lo contrario, el recurso será inadmitido (de hecho, no se podrá ni siquiera interponer, pues el nuevo esquema procesal opera sobre una previa venia que el Tribunal sentenciador debe otorgar al litigante para que recurra).

La existencia de interés casacional se podrá acreditar sobre la base de razones sólidas de carácter jurídico, económico o social, por lo que el recurrente tendrá que hacer un especial esfuerzo argumentativo para ello (art. 89.2.f).

El interés casacional no es nuevo en nuestra legislación procesal, como se ha in-

35 YABLON, R.M., "Justice Sotomayor and the Supreme Court's Certiorari Process", 123, Yale Law Fournal, 551, 2014.

36 LOZANO CUTANDA, B., op. cit.: "Con esta reforma se subjetiviza la admisión del recurso de casación, en cuanto será el Tribunal de casación quien decida si un recurso tiene o no interés casacional objetivo para la formación de jurisprudencia suprimiéndose los motivos tasados actualmente existentes".

37 CHAVES GARCÍA, J.R., "Tiempos nuevos para el recurso de casación contencioso-administrativo", Actualidad Jurídica Aranzadi, núm. 911/2015: "Además, el defecto y a la vez la mayor virtud de la reforma, radica en que la llave para la admisión de los recursos de casación la ejercerá de forma omnímoda la propia Sala Tercera, que será la llamada a apreciar el interés casacional objetivo para la formación de jurisprudencia, novedoso concepto indeterminado cuya concurrencia deberá verificarse en cada caso". 
dicado anteriormente, ni lo es en la Ley jurisdiccional. El artículo 477.3 de la LEC lo incluye, aunque no con la finalidad de inadmitir recursos: "Se considerará que un recurso presenta interés casacional cuando la sentencia recurrida se oponga a doctrina jurisprudencial del Tribunal Supremo o resuelva puntos y cuestiones sobre los que exista jurisprudencia contradictoria de las Audiencias Provinciales o aplique normas que no lleven más de cinco años en vigor, siempre que, en este último caso, no existiese doctrina jurisprudencial del Tribunal Supremo relativa a normas anteriores de igual o similar contenido”.

Y en la LJCA, antes de la reforma introducida por Ley Orgánica 7/2015, se contemplaba el interés casacional, como se ha dicho, como una causa específica de inadmisión del recurso en el artículo 93.2.e), que establecía que se dictará auto de inadmisión: "En los asuntos de cuantía indeterminada que no se refieran a la impugnación directa o indirecta de una disposición general, si el recurso estuviese fundado en el motivo del artículo 88.1. d) y se apreciase que el asunto carece de interés casacional por no afectar a un gran número de situaciones o no poseer el suficiente contenido de generalidad”. Este artículo 93.2.e) especificaba los requisitos para la aplicación de este supuesto de falta de interés casacional:

(i) que se tratase de asuntos de cuantía indeterminada que no se refirieran a la impugnación directa o indirecta de una disposición general -no a cualquier clase de asunto-;

(ii) que el recurso se fundase en el motivo del artículo 88.1.d), -y no en otra infracción de normas o de jurisprudencia-; y

(iii) que se apreciase que el asunto carecía de interés casacional por no afectar a un gran número de situaciones o por no poseer el suficiente contenido de generalidad por lo que el interés casacional de ese artículo no era amplio ni genérico, sino limitado a la concurrencia de uno de esos dos supuestos-.

Con la reforma se establecen algunos supuestos en los que el Tribunal Supremo "podrá" apreciar la existencia de interés casacional (art. 88.2), pero ni la concurrencia de esos supuestos obliga al Tribunal Supremo a declarar la existencia de interés casacional - que tendrá que valorar en cada $\mathrm{Caso}^{-}$, ni la concurrencia de situaciones distintas a las contempladas en ese art. 88.2 impide al Alto Tribunal dictar auto de admisión del recurso de casación si aprecia la existencia de interés casacional. Por tanto, esos criterios son simplemente orientadores ${ }^{38}$. El profesor Santamaría Pastor ha dicho que

38 CÓRDOBA GASTROVERDE, D., op.cit. 
los listados de supuestos de intereses casacional previstos en la Ley Orgánica 7/2015 enumeran situaciones de hecho puramente indiciarias de la existencia de un interés casacional, que pueden concurrir, o no, en cada concreto recurso, y cuya apreciación es enteramente libre por parte de la Sala ${ }^{39}$. De ahí mi crítica a esta vía de conversión de los recursos en concesiones cuasigraciables y en la espita que se abre para inadmitir casaciones al estilo de lo que se viene padeciendo ante el Tribunal Constitucional.

De acuerdo con el nuevo artículo 88.2 de la LJCA, el Tribunal de casación "podrá" apreciar que existe interés casacional objetivo, motivándolo expresamente en el auto de admisión, cuando, entre otras circunstancias, (numerus apertus) la resolución que se impugna:

a) fije, ante cuestiones sustancialmente iguales, una interpretación de las normas de Derecho estatal o de la Unión Europea en las que se fundamenta el fallo contradictoria con la que otros órganos jurisdiccionales hayan establecido -supuesto análogo al previsto para el recurso de casación para la unificación de doctrina-;

b) siente una doctrina sobre dichas normas que pueda ser gravemente dañosa para los intereses generales;

c) afecte a un gran número de situaciones, bien en sí misma o por trascender del caso objeto del proceso;

d) resuelva un debate que haya versado sobre la validez constitucional de una norma con rango de ley, sin que la improcedencia de plantear la pertinente cuestión de inconstitucionalidad aparezca suficientemente esclarecida;

e) interprete y aplique aparentemente con error y como fundamento de su decisión una doctrina constitucional;

f) interprete y aplique el Derecho de la Unión Europea en contradicción aparente con la jurisprudencia del Tribunal de Justicia o en supuestos en que aun pueda ser exigible la intervención de éste a título prejudicial;

g) resuelva un proceso en que se impugnó, directa o indirectamente, una disposición de carácter general;

39 SANTAMARÍA PASTOR, J.A., "Una primera aproximación al nuevo sistema casacional”, Revista de Administración Pública, núm. 198, 2015. 
h) resuelva un proceso en que lo impugnado fue un convenio celebrado entre Administraciones públicas; o,

i) haya sido dictada en el procedimiento especial de protección de derechos fundamentales.

Además, la Ley Orgánica 7/2015 ha establecido determinados supuestos en los que se presumirá la existencia de interés casacional objetivo. Sin embargo, esa presunción queda limitada en realidad a la letra b) del apartado 3 del artículo 88 de la LJCA: "cuando dicha resolución se aparte deliberadamente de la jurisprudencia existente al considerarla errónea”. A mi juicio este supuesto no se refiere sólo a apartarse deliberadamente y de forma expresa de la jurisprudencia existente, sino también a hacerlo de forma tácita ${ }^{40}$. Lo que exige la ley es que haya un apartamiento deliberado, y la deliberación no requiere necesariamente de un razonamiento expreso.

Se contempla otro supuesto, en la letra c) de dicho apartado, en el que se presumirá el interés casacional objetivo, aunque éste dependerá ciertamente de su apreciación por el Tribunal: “cuando la sentencia recurrida declare nula una disposición de carácter general, salvo que ésta, con toda evidencia, carezca de trascendencia suficiente”. El resto de supuestos de presunción previstos en el citado apartado 3 dará acceso a la casación salvo que el Tribunal aprecie por auto motivado que el asunto carece manifiestamente de interés casacional objetivo para la formación de la voluntad: “a) cuando en la resolución impugnada se hayan aplicado normas en las que se sustente la razón de decidir sobre las que no exista jurisprudencia; (...) d) cuando resuelva recursos contra actos o disposiciones de los organismos reguladores o de supervisión o agencias estatales cuyo enjuiciamiento corresponde a la Sala de lo Contencioso-administrativo de la Audiencia Nacional; y e) cuando resuelva recursos contra actos o disposiciones de los Gobiernos o Consejos de Gobierno de las Comunidades Autónomas".

Habrá que esperar a la formación de criterios de interpretación de dichas causas para poder valorar justamente la reforma, y, sobre todo, la aplicación que el Tribunal Supremo haga de la misma.

${ }^{40}$ En sentido contrario afirma CÓRDOBA GASTROVERDE lo siguiente: "Se podrian plantear si se incluyen en este apartado aquellos casos en los que el tribunal omite la aplicación de la jurisprudencia que ha sido invocada por la otra parte, aunque sin mencionarla de forma expresa, pero entiendo que este supuesto está excluido al exigir la norma que ese apartamiento de la jurisprudencia sea deliberado por considerar es a jurisprudencia errónea, de donde se desprende la exigencia de un razonamiento expreso destinado a inaplicarla”(CÓRDOBA CASTROVERDE, D., op.cit.). 


\section{LAS PRETENSIONES}

El artículo 87 bis apartado 2 regula por primera vez las pretensiones del recurso de casación. El recurso deberá tener por objeto la anulación, total o parcial, de la sentencia o auto impugnado y, en su caso, la devolución de los autos al Tribunal de instancia o la resolución del litigio por la Sala de lo Contencioso-Administrativo del Tribunal Supremo dentro de los términos en que apareciese planteado el debate. Podría haber incluido, para mayor precisión, el reconocimiento de situaciones jurídicas individualizadas que puede derivarse, obviamente, de la anulación de la resolución judicial; de todos modos, eso es evidente cuando la sentencia resolutoria del recurso de casación no se traduce en devolver las actuaciones al órgano judicial de procedencia.

\section{EL PROCEDIMIENTO}

\section{VIII.1. Las condiciones de los escritos}

El nuevo apartado 3 del artículo 87 bis de la LJCA establece la facultad del Tribunal Supremo de fijar requisitos de forma y de extensión en los escritos. En concreto, la Sala de Gobierno del Tribunal Supremo podrá determinar, mediante acuerdo, que se publicará en el Boletín Oficial del Estado, la extensión máxima y otras condiciones extrínsecas, incluidas las relativas a su presentación por medios telemáticos, de los escritos de interposición y oposición de los recursos de casación. Así se ha hecho, con el Acuerdo de 19 de mayo de 2016, del Consejo General del Poder Judicial, por el que se publica el Acuerdo de 20 de abril de 2016, de la Sala de Gobierno del Tribunal Supremo, sobre la extensión máxima y otras condiciones extrínsecas de los escritos procesales referidos al Recurso de Casación ante la Sala Tercera del Tribunal Supremo (BOE 06/07/2016).

La limitación de extensión de escritos es una novedad en nuestro país. No obstante, existen precedentes, pues el Tribunal de Justicia de la Unión Europea limita la extensión de los escritos (a 50 páginas en el caso de la demanda y del escrito de contestación a la demanda). También lo hace el Tribunal Supremo de los EEUU o el Tribunal Europeo de Derechos Humanos, entre otros, sin que se considere que se limita el derecho a la tutela judicial efectiva.

El profesor Santamaría Pastor ha dicho al respecto que fijar de antemano una dimensión máxima de los escritos es un perfecto disparate, producto del más rancio arbitrismo, que desconoce la radical diferencia de complejidad que existe entre unos y otros recursos (crítica que comparto). En mi opinión, es razonable que el Tribunal 
Supremo, si le habilita el legislador para ello, trate de normalizar la estructura y forma de presentación de los recursos a efectos de facilitar su lectura, o por razones de homogeneización. Pero eso es diferente de fijar a priori la extensión máxima, pues en la práctica esta dependerá de la complejidad de cada asunto y de la capacidad de síntesis de cada abogado. Me parece por ello discutible la validez constitucional de la limitación -aunque sea sana para los propios abogados-; no se pretenderá, por ejemplo, ajustar a esas dimensiones un recurso directo contra un hipotético Reglamento Hipotecario, o contra el Reglamento del IRPF, por poner algunos ejemplos.

El citado Acuerdo de la Sala de Gobierno del Tribunal Supremo regula tanto las normas para los escritos de interposición y oposición de los recursos de casación dirigidos a la Sala Tercera del Tribunal Supremo, como los criterios "orientadores" respecto de los escritos de preparación (art. 89.2 LJCA) y de oposición a la admisión (art. 89.6 LJCA). Se reitera que el art. 87 bis 3 LJCA solo habilita al Tribunal Supremo a determinar las condiciones de los escritos de interposición y de oposición.

Dicho Acuerdo establece en concreto lo siguiente: (por su importancia, y por razones de precisión, lo transcribo literalmente)

"II. Normas para los escritos de interposición y oposición de los recursos de casación dirigidos a la Sala Tercera del Tribunal Supremo.

\section{Extensión máxima.}

Los escritos de interposición y contestación tendrán una extensión máxima de 50.000 «caracteres con espacio», equivalente a 25 folios. El texto figurará en una sola cara de la hoja (anverso) y no en ambas (anverso y reverso).

Esta extensión máxima incluye las notas a pie de página, esquemas o gráficos que eventualmente pudieran incorporarse.

El Abogado, u otra persona que este designe, deberá certificar al final del mismo el número de caracteres que contiene el escrito que presenta.

\section{Formato.}

Se utilizará para el texto como fuente «Times New Román», con un tamaño de 12 puntos en el texto y de 10 puntos en las notas a pie de página o en la transcripción literal de preceptos o párrafos de sentencias que se incorporen. 
El interlineado en el texto será de 1,5.

Los márgenes horizontales y verticales (márgenes superior, inferior, izquierdo y derecho de la página) serán de $2,5 \mathrm{~cm}$.

Todos los folios estarán numerados de forma creciente, empezando por el número 1. Este número figurará en la esquina superior derecha del folio.

Todos los documentos que se aporten con el escrito deberán estar suficientemente identificados y numerados como Documento o Anexo, por ejemplo: Documento o Anexo 1, Documento o Anexo 2, Documento o Anexo 3 y así sucesivamente.

El formato electrónico del folio será A4, sin rayas ni otros elementos que dificulten su lectura o tratamiento informático. Idéntica previsión se aplicará si el documento se presenta en papel.

\section{Estructura.}

\subsection{Carátula.}

Los escritos de interposición y oposición presentados por vía telemática o en papel irán precedidos de una carátula o formulario, que generará el sistema o que rellenarán los profesionales que presenten el escrito, y que contendrá, al menos, los siguientes datos:

- Número del recurso de casación.

- Identificación de la Sala y Sección destinataria del escrito.

- Nombre del recurrente o recurrentes ordenados alfabéticamente y el número del DNI, pasaporte, NIE (en el caso de extranjeros) o NIF (en el caso de personas jurídicas). En el caso de tratarse de una Administración pública bastará con la identificación de la misma.

- Nombre del Procurador y número de colegiado.

- Nombre del Letrado/s y número de colegiado.

- Identificación de la sentencia o resolución recurrida en casación, expresando el tribunal, sala y sección de procedencia, la fecha de la resolución y el número del procedimiento. Por ejemplo: sentencia de la Sección Primera del Tribunal Superior 
de Justicia de Madrid, de 1 de enero de 2016 (procedimiento o recurso 1/2016). (este dato no será necesario cuando se trate del escrito de oposición).

- Identificación del tipo de escrito que se presenta (escrito de interposición o escrito de oposición al recurso presentado por el recurrente).

\subsection{Contenido de los escritos.}

Los escritos de interposición se estructurarán en apartados separados y debidamente numerados que se encabezarán con un epígrafe expresivo de aquello de lo que tratan, en los términos previstos en el art. 92.3 de la Ley de Jurisdicción Contencioso-Administrativa.

Igual previsión regirá para los escritos de oposición reflejando en el encabezamiento de cada apartado la cuestión que abordarán como respuesta a los contenidos en el escrito de personación o a los diferentes extremos controvertidos.

III. Criterios orientadores respecto de los escritos de preparación (art. 89.2 de la LJ) y de oposición a la admisión (art. 89.6 LJ) de los recursos de casación dirigidos a la Sala Tercera del Tribunal Supremo.

1. Extensión máxima.

Los escritos de preparación y de oposición deberían tener una extensión máxima de 35.000 «caracteres con espacio», equivalente a 15 folios, escritos solo por una cara (anverso).

Esta extensión máxima incluye las notas a pie de página, esquemas o gráficos que eventualmente pudieran incluirse en dicho escrito.

2. Formato.

Será el mismo que el previsto para los escritos de interposición y oposición.

\section{Estructura.}

\subsection{Carátula.}

Será la misma que se prevé para los escritos de interposición y oposición, con las siguientes previsiones específicas: 
- No es necesario incorporar el número del recurso de casación, dado que todavía se desconoce.

- Identificación del tipo de escrito que se presenta (escrito de preparación, de oposición a la admisión, etc...).

- Se incorporará una ventana con el rótulo «Asunto», "Objeto» o similar, en la que se hará una brevísima descripción de la materia sobre la que verse el litigio, a los simples efectos de su pronta identificación. Por ejemplo: Propiedad Industrial. Patente. Caducidad.

3.2 Contenido de los escritos.

El escrito de preparación se estructurará en apartados separados y debidamente numerados que se encabezarán con un epígrafe expresivo de aquello de lo que tratan, destacando especialmente los apartados destinados a justificar que las infracciones imputadas han sido relevantes y determinantes de la decisión adoptada en la resolución que se pretende recurrir y fundamentar, con singular referencia al caso, la concurrencia del interés casacional objetivo y la conveniencia de un pronunciamiento de la Sala de lo Contencioso-Administrativo del Tribunal Supremo, en los términos previstos en el art. 89.2 de la Ley de Jurisdicción Contencioso-Administrativa.

El escrito de oposición a la admisión se estructurará en apartados separados y debidamente numerados que se encabezarán con un epígrafe expresivo de aquello de lo que tratan.

IV. Criterios orientadores para los escritos de alegaciones (art. 90.1 de la LJ).

Extensión máxima.

La extensión máxima del escrito de alegaciones previsto en el art. 90.1 de la LJ, será fijada, en función de las circunstancias del caso, por la Sección de admisión prevista en el apartado segundo de este mismo precepto, sin que, en todo caso, pueda ser superior a la del escrito de preparación correspondiente".

\section{VIII.2. La preparación del recurso de casación}

La preparación del recurso de casación corresponde a quienes hubieran sido parte en el proceso o deberían haberlo sido ${ }^{41}$. Se prepara ante el órgano que hubiera dic-

41 STS (Sala de lo Contencioso-administrativo, Sección 5a), de 31 de enero de 2012 (RJ 2012\3704): 
tado la resolución recurrida (sea Sala o Juzgado), en el plazo de treinta días contados desde el siguiente al de la notificación de la resolución que se recurre (art. 89.1) -si se ha interpuesto recurso, el plazo contará desde el día siguiente a la notificación de la resolución del mismo-. Los plazos son por días hábiles en la sede del órgano judicial en el que haya que preparar la casación (art. 185.1 de la LOPJ).

Con la reforma, parece razonable mantener el escrito de preparación, que anteriormente era innecesario a mi juicio, pues el Tribunal Supremo, tras su presentación, tiene que dar la venia al recurrente para la interposición. Es un acierto del legislador la ampliación del plazo de presentación, anteriormente de diez días, pues era ya un plazo muy breve para cumplir adecuadamente con los rigorismos formales que el Tribunal Supremo venía imponiendo a ese trámite, -como la necesidad de anticipar en el escrito de preparación los motivos del recurso ${ }^{42}$ - y que ahora, con la reforma, se agravan. En este sentido, el rigorismo del recurso de casación debe estar muy presente en quien lo prepara, pues el incumplimiento de los requisitos formales del escrito de preparación provocaría un defecto insubsanable y su inadmisión ${ }^{43}$. Lo cierto que para

"El artículo 89.3 de la de la Ley 29/1998, de 13 de julio (RCL 1998, 1741), reguladora de este orden contenciosoadministrativo (en adelante LRFCA) dispone que "el recurso de casación podrá interponerse por quienes hayan sido parte en el procedimiento a que se contraiga la Sentencia o resolución recurrida". Tiene razón la entidad recurrida cuando aduce que la legitimación activa y pasiva en el recurso de casación viene dada en función de la calidad de parte de que se haya disfrutado en el proceso de instancia. Sin embargo la doctrina de esta Sala puntualiza [Cfr., sentencia de 15 de diciembre de 2006 (RJ 2006, 9277) (Casación 199/2004)] en una interpretación pro actione favorable al derecho a la tutela judicial efectiva, en su dimensión de derecho de acceso a la jurisdicción [Cfr., sentencia de esta Sala de 30 de diciembre de 2011 (RJ 2012, 3105) (Casación 208/2008) y las que alli se citan] que están habilitados para preparar el recurso de casación no sólo quienes hubiesen sido parte en el recurso contencioso-administrativo en que se dictó la resolución objeto de recurso sino también quienes hubieran podido serlo, lo que no supone la exigencia absoluta de haberse personado en él antes de la sentencia, pero sí, desde luego, la personación en el proceso " a quo " dentro del plazo legalmente establecido para la preparación del recurso de casación, cuyo cómputo arranca desde la última notificación hecha a quienes se hubieren personado en el procedimiento durante el curso de los autos [por todos Auto de la Sección Primera de esta Sala de 15 de febrero de 2007 GUR 2007, 109545) (Casación 5094/2005), y los que en él se citan]”. En el mismo sentido, STS (Sala de lo Contenciosoadministrativo, Sección $5^{\text {a }}$ ), de 21 de octubre de 2014 (RJ 2014\5820).

42 Sobre la constitucionalidad de este requisito vid. DOMÍNGUEZ, LUIS, J.A., "Constitucionalidad de los criterios jurisprudenciales relativos a los requisitos del escrito de preparación del recurso de casación en el orden contenciosoadministrativo: la anticipación de los motivos e infracciones que sirven de fundamento al recurso", Revista Aranzadi Doctrinal, núm. 9, 2015. Asimismo, MUÑOZ ARANGUREN, A., “¿Ad impossibilia nemo tenetur? Depende: la Sentencia del Tribunal Constitucional 7/2015, de 22 de enero, sobre los nuevos requisitos formales del escrito de preparación del recurso de casación en la jurisdicción contencioso-administrativa exigidos por el Tribunal Supremo", Revista Española de Derecho Administrativo, núm. 170, 2015.

${ }^{43}$ ATS (Sala de lo Contencioso-administrativo, Sección $1^{\text {a }}$ ), de 24 de noviembre de 2011 (JUR 2012\21400): "No es ocioso recordar que el Tribunal Constitucional ha considerado conformes con el artículo 24 de la Constitución las dos interpretaciones defendidas por esta Sala: de un lado, que la carga procesal exigible a quien prepara el recurso de casación no se libera citando de forma apodíctica las normas estatales o comunitarias europeas que se reputen infringidas sin añadir justificación alguna, es decir, omitiendo el juicio de relevancia legalmente exigible; $y$, de otro, que el defecto de justificación apreciable en el escrito de preparación no es subsanable en el escrito de interposición (STC 181/2001, de 17 de septiembre (RTC 2001, 181 )) y ATC 3/2000, de 10 de enero (RTC 2000, 3), que señaló que "tampoco cabe apreciar vulneración del derecho 
afrontar un recurso de casación hay que conocer muy bien los criterios jurisprudenciales que restringen un recurso como éste -que es de naturaleza extraordinaria-, y ahora, además, el resto de criterios que se han introducido en la LJCA. Lo que no sería admisible desde un punto de vista constitucional es que un cambio en los criterios del Tribunal Supremo sobre los requisitos del escrito de preparación pudiera aplicarse con efectos retroactivos ${ }^{44}$.

El órgano ante el que debe prepararse el recurso de casación comprobará inicialmente el cumplimiento de los requisitos, aunque la admisión corresponderá al Tribunal Supremo. Por ello, al escrito de preparación debe acompañarse el documento que acredite el depósito para recurrir, copias del escrito de preparación para las partes, documentos que justifiquen la legitimación o la representación si no constaran en autos, y otros documentos que puedan facilitar la admisión.

Los requisitos formales que se exigen al escrito de preparación son los siguientes (art. 89.2):

a) acreditar el cumplimiento de los requisitos reglados en orden al plazo, la legitimación y la recurribilidad de la resolución que se impugna. El plazo es improrrogable y preclusivo. Aunque la legitimación debe reconocerse a quien ha sido parte en el proceso, conviene en todo caso razonar la legitimación. Y se ha de justificar que la resolución que se recurre es recurrible en casación conforme a los preceptos correspondientes. Se ha suprimido el requisito del anterior artículo 89.1 de manifestar la intención de interponer el recurso, aunque quizás convenga mantenerlo para evitar sorpresas interpretativas, con indicación clara de la resolución que se pretende recurrir y la debida denominación del recurso para eludir su inadmisión. Ahora que se han suprimido los recursos de casación para la unificación de la doctrina y en interés de ley se producirán menos confusiones en la preparación de los recursos, pues no era una cuestión baladí en la práctica. En alguna ocasión el error puede tener origen en la indicación de recursos que se haga en la resolución impugnada. A diferencia de lo que sucede en vía administrativa, donde el error en la indicación de recursos por parte de la Administración no puede perjudicar al recurrente, es doctrina del Tribunal Supremo que dicho error en la resolución judicial no exime de la carga de interponer el recurso pertinente en los casos en que se cuente con asistencia letrada ${ }^{45}$. En todo caso,

a la tutela judicial efectiva sin indefensión (art. $24.1 \mathrm{CE}$ ) en la interpretación sostenida por la Sala Tercera del Tribunal Supremo acerca de la no subsanabilidad del defecto de incumplimiento de la carga prevista en el art.96.2 LFCA (RCL 1998, 1741), por estimar que se trata de un vicio sustancial insubsanable y que el art. 129 LFCA sólo permite subsanar los defectos formales, no los de carácter material o sustancial" ( $\left.F^{\circ} \mathcal{F}^{\circ} 5\right)$ ".

44 STG (Sala Pleno), núm. 7/2015, de 22 de enero (RTG 2015 7).

45 Dice la STS (Sala de lo Contencioso-administrativo, Sección 6 $6^{\text {a) }}$ de 22 de octubre de 2010 (RJ $2011 \backslash 1362)$ : "Y aunque es cierto que al notificarse la sentencia por el tribunal "a quo" se indicó que contra la misma $<<$ sólo cabe interponer el recurso de casación para la unificación de doctrina..... $>>$ y que $<<$ Asimismo, podrá interponer contra ella 
no parece de recibo que se obligue al recurrente a exponer lo que es obvio y conocido fácilmente por el Tribunal;

b) Identificar con precisión las normas o la jurisprudencia (de dos o más sentencias, pues no basta una sola) que se consideran infringidas, justificando que fueron alegadas en el proceso, o tomadas en consideración por la Sala de instancia, o que ésta hubiera debido observarlas aun sin ser alegadas (habría que entender, aunque no hayan sido alegadas por las partes; ya antes me referí a ello). Aunque la norma dice solamente que hay que "identificar" la norma y la jurisprudencia, y podría entenderse que ello equivale a su mención estricta, conviene precisar que no se pueden alegar infracciones genéricas y que para una mejor fundamentación resultará oportuno justificar la infracción. El análisis jurisprudencial exige una comparativa detallada de los criterios interpretativos del Tribunal Supremo en varios supuestos y el caso objeto del recurso. Hay que recordar que desde el año 2010 el Tribunal Supremo endureció su interpretación de los requisitos formales del artículo 89.1 y exigió señalar en el escrito de preparación exactamente cuáles eran las infracciones que se imputaban a la sentencia que se trataba de recurrir, e incluso sobre la base de qué apartado concreto del artículo 88.1 se invocaría cada una de ellas al interponer en su día el recurso ${ }^{46}$. El legislador ha consagrado en la norma este criterio del Tribunal Supremo.

c) acreditar, si la infracción imputada lo es de normas o de jurisprudencia relativas a los actos o garantías procesales que produjo indefensión, que se pidió la subsanación de la falta o transgresión en la instancia, de haber existido momento procesal oportu-

cualquier otro recurso que estime adecuado a la defensa de sus intereses $>>$, también lo es que contra dicha notificación no se interpuso recurso alguno y que según doctrina reiterada de esta Sala (por todos, autos de 20 de septiembre de 1999 (R7 2009 , 7506) y 16 de octubre de 2000 (JUR 2001, 488) o sentencia de 21 de julio de de 2006 (RJ 2006, 5851)) sobre la parte recurrente pesa la carga de preparar o, en su caso, interponer, dentro de plazo, el recurso de casación que proceda, abstracción hecha de la advertencia meramente informativa que dispone el artículo 248.4 de la Ley Orgánica del Poder Fudicial (RCL 1985, 1578, 2635) cuando, como aquí ocurre, aquélla está asistida de letrado". Importancia de la STC En página 16 nota 43 en cuando al fondo se puede desarrollar más la importancia de la STG 7/2015 de 22 de enero relativa a la infracción del art. 24.1 CE por los escritos de preparación de la casación.

Se puede citar la STC 88/2015 de 15 de abril, que desestima un recurso de amparo y confirma la inadmisión de un recurso de casación. Esta STC indica la situación distinta respecto a la STC 7/2015 de 22 de enero. En el último párrafo del FJ 3 de la STC 88/2015 se dice: "Por lo demás, no concurren las excepcionales circunstancias apreciadas en el caso resuelto en la STC 7/2015, de 22 de enero, en el que la parte, con notoria diligencia, procedió a complementar el escrito de preparación inicialmente presentado para ajustarlo al nuevo criterio jurisprudencial tan pronto como tuvo conocimiento de ello, conducta procesal que el Tribunal Supremo no ponderó, lesionando así el derecho fundamental reconocido en el art. 24.1 CE. En este caso, sin embargo, la parte no procedió del modo expuesto, ni siquiera después de que le fuera notificada la providencia mediante la que el Tribunal Supremo abría el trámite de alegaciones sobre la posible concurrencia de la causa de inadmisión derivada del defecto advertido".

${ }_{46}$ GARCíA-TREVIJANO GARNICA, J.A., "A cuestas con el formalismo procesal", Diario La Ley, núm. 7681, Sección Tribuna, 26 de julio de 2011. 
no para ello ${ }^{47}$. Esto obliga a las partes a recurrir o protestar ad cautelam sin conocer realmente en muchos casos el alcance de la infracción, que se pondrá de manifiesto en la resolución final objeto de la casación. Por ello dice Santamaría Pastor que es una exigencia disfuncional que trufa el proceso de recursos e incidentes continuos dilatando su tramitación ${ }^{48}$, pues si se consiente una resolución judicial que infringe normas o jurisprudencia (por ejemplo, una providencia) se podría inadmitir el recurso de casación contra el auto o sentencia correspondiente.

d) acreditar que la o las infracciones imputadas han sido relevantes y determinantes de la decisión adoptada en la resolución que se pretende recurrir (tienen que ser fundamento jurídico de la decisión). Esta letra enlaza con la letra b) por lo que está claro que no basta con identificar la infracción.

e) justificar, en el caso de que ésta hubiera sido dictada por la Sala de lo Contencioso-Administrativo de un Tribunal Superior de Justicia, que la norma supuestamente infringida forma parte del Derecho estatal o del de la Unión Europea (pues de lo contrario no cabría recurso de casación ante el Tribunal Supremo). Cuando se ha aplicado Derecho autonómico, estatal y de la Unión Europea habrá que justificar que la aplicación en ese caso concreto del Derecho estatal o de la Unión Europea es fundamental. y,

f) especialmente, fundamentar con singular referencia al caso, que concurren alguno o algunos de los supuestos que, con arreglo a los apartados 2 y 3 del artículo anterior, permiten apreciar el interés casacional objetivo y la conveniencia de un pronunciamiento de la Sala de lo Contencioso-Administrativo del Tribunal Supremo, por lo que es esencial convencer al Tribunal Supremo de la relevancia del asunto desde un punto de vista jurídico, económico o social.

Si no se presenta el escrito de preparación en el plazo de treinta días, la resolución judicial susceptible de casación quedará firme, y el Letrado de la Administración de Justicia (anteriormente denominado Secretario Judicial) deberá dictar un decreto en el que declare su firmeza. Como se ha indicado anteriormente, contra las resoluciones firmes puede interponerse recurso de revisión (art. 89.3).

47 STS (Sala de lo Contencioso-administrativo, Sección 5a) de 12 de julio de 2012 (RJ 2012\8651): "En este aspecto ha de recordarse que, a tenor del artículo 88.2 de la LRFCA (RCL 1998, 1741), la infracción de las normas relativas a los actos y garantías procesales que produzca indefensión "sólo podrá alegarse cuando se haya pedido la subsanación de la falta o transgresión en la instancia, de existir momento procesal oportuno para ello", y en este caso, como se ha dicho, el aquí recurrente no impugnó, pudiendo hacerlo, el citado Auto de 21 de enero de 2009".

48 SANTAMARÍA PASTOR, J.A., op.cit. 
Si el escrito de preparación no cumple los requisitos señalados anteriormente [letras a) a f)], el órgano de instancia deberá dictar auto motivado por el que no tendrá por preparado el recurso y denegará el emplazamiento de las partes y la remisión de las actuaciones al Tribunal Supremo. Contra este auto denegatorio se puede interponer recurso de queja (art. 89.4).

Si, por el contrario, se cumplen los requisitos del escrito de preparación señalados anteriormente, el órgano de instancia debe dictar auto, en el que motive suficientemente su concurrencia, y tendrá por preparado el recurso de casación, ordenará el emplazamiento de las partes para su comparecencia dentro del plazo de treinta días ante la Sala de lo Contencioso-Administrativo del Tribunal Supremo, así como la remisión a ésta de los autos originales y del expediente administrativo. Señala al respecto Santamaría Pastor que no se entiende que se mantenga un plazo de igual duración para llevar a cabo la personación ante el Tribunal Supremo cuando el órgano judicial a quo haya tenido por preparado el recurso, porque tras la reforma, el trámite de personación del recurrente no ha de ir acompañado del escrito de interposición, cuya presentación sólo procederá una vez que el recurso de casación haya sido admitido por la Sala Tercera (art. 91.2) $)^{49}$.

Si el órgano de instancia lo entiende oportuno, emitirá una opinión sucinta y fundada sobre el interés objetivo del recurso para la formación de jurisprudencia, que unirá al oficio de remisión (art. 89.5). No debe confundirse por tanto el contenido del auto (sobre el cumplimiento de los requisitos reglados y la justificación del cumplimiento de los del art. 89.2) con el de la opinión sucinta (sobre la concurrencia en el caso concreto de interés objetivo del recurso para la formación de la jurisprudencia). La finalidad de esta opinión es ilustrar al Tribunal Supremo sobre los asuntos que pueden tener interés casacional. Se parte por ello de la idea de que el órgano de instancia es independiente y que, por tanto, su informe se emitirá cuando corresponda, y será objetivo y de ayuda para el Alto Tribunal. Sin embargo, siendo cierto que los Tribunales son independientes, se olvida que, por coherencia, el Juez ha de defender las resoluciones que dictó, y que ello puede influir en la consecución de este trámite.

La preparación del recurso de casación no impide la ejecución provisional de la sentencia (art. 91) y la parte recurrida no puede interponer recurso alguno contra el auto en que se tenga por preparado el recurso de casación (art. 89.6).

${ }^{49}$ SANTAMARÍA PASTOR, J.A., op.cit. 


\section{VIII.3. La admisión o inadmisión a trámite del recurso}

La admisión o inadmisión a trámite del recurso preparado, que está prevista antes de la interposición, deberá ser decidida por una Sección de la Sala de lo Contencioso-Administrativo del Tribunal Supremo integrada por el Presidente de la Sala y por al menos un Magistrado de cada una de las restantes Secciones, a propuesta del Magistrado ponente (ya se dijo que cabe recurso de casación ante Tribunales Superiores de Justicia). Con excepción del Presidente de la Sala, la composición de la misma se renovará por mitad transcurrido un año desde la fecha de su primera constitución y en lo sucesivo cada seis meses, mediante acuerdo de la Sala de Gobierno del Tribunal Supremo, que determinará sus integrantes por cada uno de los citados periodos, y que se publicará en la página web del Poder Judicial (art. 90.2). Se refiere a esta cuestión el Acuerdo de 30 de junio de 2016, de la Comisión Permanente del Consejo General del Poder Judicial, por el que se publica el Acuerdo de 14 de junio de 2016 de la Sala de Gobierno del Tribunal Supremo que aprueba las normas de reparto, composición, funcionamiento y asignación de ponencias de la Sala Tercera para su adecuación a la nueva regulación del recurso de casación en lo contencioso-administrativo (BOE núm. 163, de 7 de julio de 2016).

Finalmente, la Sección Primera (de Admisión), está presidida por el Presidente de la Sala, y por dos Magistrados procedentes de cada una de las Secciones de la Segunda a la Quinta.

La admisión del recurso se traduce en que la casación pasa a ser una impugnación sometida a previa venia del Tribunal final que debe resolver el recurso.

Sería deseable, como han señalado previamente otros autores, que la Sección Primera actuara como un verdadero órgano colegiado en el que se debatieran los asuntos, y que no se tendiera al error, de ser un órgano que se limite simplemente a ratificar las decisiones del ponente ${ }^{50}$. Por otro lado la variación en la composición de la Sección de Admisión, que se ha previsto en la norma, como ha señalado la doctrina, es una ocurrencia del legislador que puede dar lugar a cambios inesperados de los criterios de admisión que generen inseguridad jurídica en los recurrentes ${ }^{51}$. El Tribunal Supremo

50 En este sentido vid. GARCÍA-TREVIJANO, J.A., y BLANQUE REY, L., "Notas sobre la pretendida reforma de la legislación procesal", Diario La Ley, No 7602, Sección Tribuna, 1 de abril de 2011.

51 LOZANO CUTANDA, B., op. cit.: "La variación de la composición de la Sala de admisiones cada seis meses puede ocasionar que, los ya de por sí jurídicamente indeterminados criterios de admisión, sufran variaciones constantes en su interpretación según la composición de la Sala, añadiendo inseguridad jurídica al proceso de admisión". En el mismo sentido vid. FERNANDEZ FARRERES, G., op.cit.: "La Sección de admisión, por tanto, queda sujeta a una continua rotación, cada seis meses, que quizá puede dificultar el asentamiento de criterios uniformes en la aplicación de los requisitos de admisión y, en especial, en el entendimiento y apreciación de cuándo concurre interés casaciones". 
deberá articular las medidas necesarias para generar en los recurrentes cierta previsibilidad sobre sus criterios.

En la nueva redacción del artículo 90 de la LJCA se ha previsto una vista oral previa a la admisión que es potestativa, tras la recepción de los autos originales y del expediente administrativo en la Sección de la Sala de lo Contencioso-Administrativo del Tribunal Supremo. Este trámite es excepcional, por lo que sólo se acordará si las características del asunto lo aconsejan, y en su caso, por plazo común de treinta días. La finalidad del trámite es oír a las partes personadas para que se posicionen en relación con la existencia del interés casacional. Quiere ello decir que podría acordarse la inadmisión del recurso sin oír a las partes.

La resolución que se dicte sobre la admisión o inadmisión podrá tener forma de providencia (lo que constituye una novedad) o de auto, en función de las circunstancias que se precisan en el artículo 90.3 de la LJCA:

a) En los supuestos del artículo 88.2, en los que ha de apreciarse la existencia de interés casacional objetivo para la formación de jurisprudencia, tendrá forma de providencia si decide la inadmisión, y de auto, si decide la admisión (debería ser al revés; la señalada regla confirma la posición psicológica del legislador, que dificulta la admisión y facilita la inadmisión en términos de pura forma de la decisión).

Las providencias de inadmisión deberán indicar si concurre alguna de las siguientes circunstancias: (i) ausencia de los requisitos de plazo, legitimación o recurribilidad de la resolución impugnada; (ii) incumplimiento de cualquiera de las exigencias que el artículo 89.2 impone para el escrito de preparación; (iii) no ser relevante y determinante del fallo ninguna de las infracciones denunciadas; o (iv) carencia en el recurso de interés casacional objetivo para la formación de jurisprudencia. Los autos de admisión deben indicar con precisión las cuestiones en las que se entiende que existe interés casacional objetivo e identificar la norma o normas que sean objeto de interpretación.

Si se emitió opinión fundada y favorable a la admisión del recurso, la inadmisión debe acordarse por auto motivado.

b) Por el contrario en los supuestos del artículo 88.3, en los que se presume la existencia de interés casacional objetivo, la inadmisión debe acordarse por auto motivado (no por providencia como en los supuestos del art. 88.2) en el que se justifique que concurren las salvedades que se establecen en dicho artículo. 
Dictada la providencia o el auto de admisión o inadmisión no cabrá recurso alguno, y el Letrado de la Administración de Justicia de la Sala deberá comunicar al órgano que dictó la resolución recurrida la decisión adoptada. Si la decisión fuera de inadmisión deberá devolver las actuaciones procesales y el expediente recibido.

Como novedad adicional se ha previsto la publicación en la página web del Tribunal Supremo de los autos de admisión (no de los de inadmisión, providencias o sentencias, que serían más útiles), y la publicación semestralmente, tanto en dicha web como en el Boletín Oficial del Estado, de un listado de los recursos de casación admitidos a trámite, con mención sucinta de la norma o normas que serán objeto de interpretación y de la programación para su resolución ${ }^{52}$.

Sería útil, no sólo a efectos de una mayor transparencia, sino de un control más efectivo de la actuación administrativa, y de la rendición de cuentas del propio Poder Judicial, que esa información se facilitara con mayor frecuencia y que se interconectara con las sentencias que se dicten en casación, con las sentencias objeto de recurso y con las resoluciones o actuaciones administrativas que fueron recurridas, y que se publicara igualmente a través de Internet.

Finalmente, la inadmisión a trámite del recurso comportará la imposición de las costas a la parte recurrente, pudiendo tal imposición ser limitada a una parte de ellas o hasta una cifra máxima.

\section{VIII.4. La interposición del recurso y la oposición}

A diferencia de lo que sucedía en la anterior redacción de la LJCA, y como resulta de lo expuesto, la interposición del recurso será posterior a la admisión (venia).

Una vez que se haya admitido a trámite el recurso, el Letrado de la Administración de Justicia de la Sección de Admisión de la Sala de lo Contencioso-Administrativo del Tribunal Supremo, deberá dictar diligencia de ordenación para la remisión de las actuaciones a la Sección de dicha Sala que sea competente para su tramitación y decisión. En dicha diligencia se tiene que hacer saber a la parte recurrente que dispondrá de un plazo de treinta días, a contar desde la notificación de aquélla, para presentar en la Secretaría de esa Sección competente el escrito de interposición del recurso de casación. Durante ese plazo de treinta días, las actuaciones procesales y el expediente administrativo estarán de manifiesto en la Oficina judicial (por lo que no

52 http://www.poderjudicial.es/cgpj/es/Poder-Judicial/Tribunal-Supremo/Recurso-de-CasacionContencioso-Administrativo--L-O--7-2015-/Listado-de-recursos-admitidos-a-tramite/ 
se entregarán, lo que dificulta el trabajo del recurrente). Si transcurriera ese plazo sin que se presentara el escrito de interposición se declararía desierto el recurso.

El escrito de interposición debe cumplir también una serie de formalidades:

(i) debe estructurarse en apartados separados con un epígrafe que exprese aquello de lo que tratan;

(ii) debe exponer razonadamente por qué han sido infringidas las normas o la jurisprudencia que como tales se identificaron en el escrito de preparación con su cita correcta y precisa ${ }^{53}$. No puede extenderse a otras normas o sentencias no consideradas entonces, pues está prohibido el planteamiento de cuestiones nuevas ${ }^{54}$. No puede limitarse a citar las sentencias del Tribunal Supremo que se consideren infringidas, sino que debe analizarlas para justificar su aplicabilidad al caso. El análisis jurisprudencial debe ser riguroso y completo, por lo que no puede limitarse a fragmentos aislados de sentencias que no contengan la ratio decidendi o que no respondan adecuada y cumplidamente al asunto objeto del recurso ${ }^{55}$. Téngase en cuenta, aunque la norma

53 Auto del Tribunal Supremo (Sala de lo Contencioso-administrativo, Sección 1 a), de 3 de noviembre de 2011 (JUR 2011 422358): "Debe, sin embargo, inadmitirse el motivo tercero, pues (aparte de la cita escueta e insuficiente de una sola sentencia de este Tribunal Supremo) no se expone en dicho motivo cuáles son los preceptos o la jurisprudencia que se consideran infringidos, lo que constituye un flagrante incumplimiento de la carga establecida en el artículo 92.1 de la Ley furisdiccional".

54 STS (Sala de lo Contencioso-administrativo, Sección 5a), de 2 de septiembre de 2015 ( RJ 2015\4340): "Así, la sentencia de 5 de julio de 1996 (R7 1996, 5966) -recurso 4689/1993 - señala que queda vedado un motivo de casación que, al amparo del artículo 95.1.4 de la anterior Ley de la Jurisdicción (RCL 1956, 1890) suponga "el planteamiento por el recurrente de cuestión nueva que no haya sido suscitada en la instancia y que, por consiguiente, no haya sido objeto de controversia ni de decisión en la sentencia recurrida, y ello por dos razones, por una parte, porque el recurso de casación tiene como finalidad propia valorar si se infringieron por el Tribunal $<<a$ quo $>>$ normas o jurisprudencia aplicable ...... y resulta imposible, ni siquiera como hipótesis, que pueda producirse aquella infracción en relación con una cuestión que ni siquiera fue considerada y sobre la que, por tanto, no hubo pronunciamiento en la sentenciaomisión que, en su caso, de entenderse improcedente, tendría su adecuado cauce revisor en el de la incongruencia omisiva-, y por otra parte, porque tan singular $<<$ mutatio libelli $>>$ afectaría al mismo derecho de defensa del recurrido (art. $24.1 \mathrm{CE}$ (RCL 1978, 2836)), en el supuesto de que, sin las posibilidades de la alegación y de la prueba que corresponden a la instancia, se entendiera admisible el examen y decisión de una cuestión sobrevenida a través del recurso de casación con las limitaciones que comporta su régimen respecto a dichos medios de defensa (sentencias de 16 (Rf 1995, 421) y 18 de enero (Rf 1995, 368), 11 (Rf 1995, 2101) y 15 de marzo de 1995 (Rf 1995, 2482), por todas las que rechazan el planteamiento en casación de cuestiones nuevas)"'”.

55 STS (Sala de lo Contencioso-administrativo, Sección 4 ${ }^{\text {a }}$ ) de 1 de junio de 2012 (RJ 2013 2322): "Precisamente por ello, y atendiendo al carácter extraordinario del recurso de casación que tiene por finalidad revisar la interpretación y aplicación de la Ley efectuada por la sentencia de instancia, esta Sala ha declarado con reiteración que el recurso de casación no puede dirigirse frente a argumentaciones de la Sentencia recurrida que constituyen "obiter dicta "pero no la "ratio decidendi ", y que aquéllas resultan irrelevantes a la hora de fundamentar el recurso de casación (ATS de 5 de mayo de 2011, con cita de las Sentencias de 21 de Fulio de 2003 (R7 2003, 5972), recurso nº 4597/1999; de 28 de Septiembre de 2004 
no lo diga expresamente, que el recurso de casación tiene por objeto la anulación de autos o sentencias y que, por tanto, se exigirá una crítica razonada a la sentencia recurrida, más allá de lo expuesto inicialmente en el escrito de preparación, pues lo que se recurre es una resolución judicial. Por tanto, es fundamental para una correcta articulación del recurso de casación combatir la fundamentación jurídica de la resolución recurrida ${ }^{56}$. El recurso de casación no puede ser una reiteración de lo alegado en instancia, sino un razonamiento crítico y sólido de los errores concretos de la fundamentación jurídica de la resolución recurrida; y,

(iii) por último, debe precisar el sentido de las pretensiones que la parte deduce y de los pronunciamientos que solicita.

Se sigue tratando por tanto -incluso en su forma- de un recurso de casación, que no puede alcanzar a debatir sobre los hechos (art. 87 bis. 1; aunque, como hasta ahora, la sentencia que resuelva el recurso de casación "podrá integrar en los hechos admitidos como probados por la Sala de instancia aquellos que, habiendo sido omitidos por ésta, estén suficientemente justificados según las actuaciones y cuya toma en consideración resulte necesaria para apreciar la infracción alegada de las normas del ordenamiento jurídico o de la jurisprudencia, incluso la desviación de poder” -art. 93.3).

Si el escrito de interposición no cumple lo exigido por la LJCA, se dará audiencia a la parte recurrente sobre el incumplimiento detectado y, sin más trámite, se dictará sentencia por la que se inadmita el recurso si se entendiera, tras la audiencia, que el incumplimiento fue cierto. En esa sentencia se impondrá, a dicha parte, las costas causadas, pudiendo tal imposición ser limitada a una parte de ellas o hasta una cifra máxima. En otro caso, se dará traslado del escrito de interposición a la parte o partes recurridas y personadas para que puedan formular escrito de oposición al recurso en el plazo común de treinta días. Durante ese plazo estarán de manifiesto las actuaciones procesales y el expediente administrativo en la Oficina judicial.

Dice ahora la LJCA que en el escrito de oposición no se puede pretender la inadmisión del recurso, lo que es criticable, pues, aunque el Tribunal Supremo (o TSJ) que deba pronunciarse $a b$ initio sobre la admisibilidad del recurso puede oír a las otras partes

(R7 2004, 6333), recurso $n^{\circ} 4743 / 2002 ;$ de 15 de Febrero de 2005 (R7 2005, 1925), recurso $n^{\circ} 7168 / 2001 ; y$ de 14 de Marzo de 2005 (Rf 2005, 3788), recurso n³147/2000)".

56 STS (Sala de lo Contencioso-administrativo, Sección $4^{\text {a }}$ ) de 1 de junio de 2012 (RJ 2013\2322): "En los mismos términos, el ATS de 28 de noviembre de 1997, recurso $n^{0} 5746 / 1997$, recoge como característica esencial del recurso de casación que la crítica del recurrente se dirija contra los fundamentos jurídicos en los que se apoya el fallo para conseguir, en su caso, la anulación (que no modificación) del mismo como consecuencia de la estimación de todos o de alguno de los motivos aducidos, por la que aquélla no puede centrarse en fundamentos jurídicos utilizados "obiter dicta "por la sentencia recurrida". 
(art. 90.1), es decisión discrecional suya. Como ni siquiera -a diferencia de lo que hasta la reforma decía la LJCA- al personarse ante el Tribunal que deba decidir puedan las partes impugnantes oponerse a la admisibilidad, se limitarán las posibilidades de defensa de la parte recurrida. Por ello no me parece ajustada al artículo 24 de la Constitución la señalada previsión, sino que la parte recurrida podrá oponerse también a la admisión -al menos si no se le ha oído en el incidente-, y sobre ello deberá decidirse en sentencia.

Otra cosa es que, si se ha oído a las partes, la resolución de admisión haya querido ser configurada por el legislador como una decisión final inatacable y no ya como una decisión de trámite revisable en la sentencia final.

\section{VIII.5. Vista}

La celebración de vista en casación está prevista en dos supuestos:

(i) cuando lo solicite alguna de las partes por medio de otrosí en los escritos de interposición y oposición, y la Sala la considere pertinente, y,

(ii) cuando la Sala lo estime necesario (de oficio, dice el art. 92.6 LJCA).

\section{VIII.6. Sentencia}

La sentencia resolverá las cuestiones y pretensiones deducidas en el proceso, sin quedar limitada a las planteadas en el auto de admisión, y anulará la sentencia o auto recurrido, en todo o en parte, o lo confirmará.

No se menciona en la redacción del precepto el reconocimiento de situaciones individualizadas conforme a las pretensiones, aunque se entiende implícito, ni se contempla expresamente la sentencia de inadmisión ${ }^{57}$, tema éste al que ya me he referido.

En otro caso, la sentencia ordenará la retroacción de las actuaciones a un momento determinado del procedimiento de instancia.

Es llamativo que la retroacción no se constriña al hecho de haberse cometido infracciones procesales, pues bajo la redacción actual de la LJCA, queda a libre albedrío del Tribunal sentenciador el hacerlo incluso cuando la infracción es de fondo o afecta a la sentencia misma (por ejemplo, por incongruencia).

\footnotetext{
57 SANTAMARÍA PASTOR, J.A., op.cit.
} 
Sostiene el profesor Santamaría Pastor que hubiera sido preferible establecer una regla según la cual la retroacción de actuaciones solo procediera en los casos en que la Sala Tercera no se encontrara en condiciones de dictar una resolución de fondo sobre las pretensiones materiales de la parte recurrente sin celebrar nuevas actuaciones probatorias ${ }^{58}$.

Si el órgano de la Jurisdicción Contencioso-Administrativa que resolvió el proceso contencioso no fuera competente, el Tribunal Supremo anulará la resolución recurrida e indicará cual es el orden competente. Si apreciara que el órgano judicial de instancia no era competente, se remitirán las actuaciones al órgano judicial que hubiera debido conocer de ellas.

Como ya se dijo, y al igual que sucedía antes de la Ley Orgánica 7/2015, el Tribunal Supremo, en su resolución, puede integrar los hechos que, habiendo sido omitidos por la Sala de instancia, estén suficientemente justificados según las actuaciones y si su toma en consideración resulta necesaria para apreciar la infracción alegada de las normas del ordenamiento jurídico o de la jurisprudencia, incluso la desviación de poder. Como indican García de Enterría y Fernández Rodríguez, los hechos, como tales, están ciertamente, excluidos de la casación, pero una cosa es eso y otra muy distinta, como bien dicen estos autores, que la sentencia de instancia seleccione a su arbitrio lo que el Tribunal Supremo haya de tener en cuenta a la hora de decidir el Derecho que a esos hechos corresponde. Distinta es también a la existencia misma de los hechos, dicen los citados profesores, la cuestión de la valoración jurídica que de esos hechos (de todos los que resulten del expediente administrativo y de la prueba eventualmente practicada en primera instancia y no de una parte de los mismos) haya podido hacer el juzgador en aplicación de los preceptos legales pertinentes y el marco de los principios generales del Derecho que vertebran el ordenamiento jurídico, entre los cuales, por supuesto, figura el de interdicción de la arbitrariedad (art. 9.3 de la Constitución), que condena toda decisión de los poderes públicos cuando no sea clara la incongruencia o discordancia (de la misma) con la realidad que es su presupuesto inexorable ${ }^{59}$.

Conviene recordar que la revisión en casación de la prueba de instancia es muy limitada. Basta mencionar la STS (Sala de lo Contencioso-administrativo, Sección $7^{\mathrm{a}}$ ), de 22 de julio de 2015 (RJ 2015 \3951), que recoge el criterio de la de 14 de febrero de 2012 (RJ 2012 \3984) y otras que se citan en ésta. Los temas probatorios que pueden ser tratados en casación, de acuerdo con la citada jurisprudencia, son: "(1) la vulneración de las reglas que rigen el reparto de la carga de la prueba; (2) la indebida

\footnotetext{
58 SANTAMARÍA PASTOR, J.A., op.cit.

59 GARCÍA DE ENTERRÍA, E., y FERNÁNDEZ RODRÍGUEZ, T.R., Curso de Derecho Administrativo II, Civitas, 1999, pág. 656.
} 
denegación, bien del recibimiento del pleito a prueba, bien de alguno o algunos de los medios de prueba propuestos; (3) la infracción de las normas relativas a la prueba tasada o a la llamada prueba de presunciones; (4) la infracción de las reglas de la sana crítica cuando la apreciación de la prueba se haya realizado de modo arbitrario o irrazonable o conduzca a resultados inverosímiles; (5) la infracción cometida cuando, al socaire de la valoración de la prueba, se realizan valoraciones o apreciaciones erróneas de tipo jurídico; (6) los errores de este tipo cometidos en los dictámenes periciales, documentos o informes, que, al ser aceptados por la sentencia recurrida, se convierten en infracciones del ordenamiento jurídico imputables directamente a ésta; y (7) por último, la integración en los hechos admitidos como probados por la Sala de instancia de aquellos otros que, habiendo sido omitidos por ésta, estén suficientemente justificados según las actuaciones y cuya toma en consideración resulte necesaria para apreciar la infracción alegada”.

Por lo demás, la sentencia debe resolver las costas de instancia y, con respecto a las de casación se introduce la novedad de que la sentencia dispondrá que cada parte abone las causadas a su instancia y las comunes por mitad. No obstante, la sentencia podrá imponer las del recurso de casación a una sola de ellas cuando aprecie, y así lo motive, que ha actuado de mala fe o con temeridad; imposición que podrá limitar a una parte de ellas o hasta una cifra (art. 93).

\section{GONGLUSIONES}

La reforma introducida por la Ley Orgánica 7/2015 sobre el recurso de casación contencioso-administrativo se ha tratado de justificar (eufemísticamente) en la intensificación de las garantías en la protección de los derechos de los ciudadanos, para lo cual, dice la Exposición de Motivos, se ha optado por reforzar el recurso de casación como instrumento por excelencia para asegurar la uniformidad en la aplicación judicial del derecho. Si bien es cierto que, efectivamente, se ha reforzado la función unificadora del Ordenamiento, ello no conlleva necesariamente una mayor protección de los derechos de los ciudadanos, -salvo en cierto sentido, del principio de igualdad y de la seguridad jurídica-. Al contrario, el nuevo modelo de recurso de casación impedirá el acceso a la misma a asuntos, que con el anterior sistema eran recurribles ante el Tribunal Supremo en casación, en los que no se aprecie la concurrencia del llamado interés casacional.

Dicha reforma debió ir unida, a mi juicio, a una atribución general de competencia inicial de todo contencioso a los Juzgados, con apelaciones posteriores generalizadas. Al no haberse alterado el régimen, multitud de asuntos, -agravando lo que ya sucedió antes de la Ley Orgánica 7/2015-, serán resueltos en una sola instancia o por 
un solo órgano jurisdiccional, lo que parece gravísimo atendiendo a la realidad inexorable de la falibilidad humana, -aunque lo permita el Tribunal Constitucional desde la perspectiva del derecho a la tutela judicial efectiva-.

La interpretación del interés casacional (que convierte la casación en un recurso a interponer previa venia y criterio del Tribunal sentenciador) estará en manos del Tribunal Supremo (o de los Tribunales Superiores de Justicia en caso de recursos a interponer ante ellos), por lo que, si realizan una interpretación muy restrictiva de dicho concepto jurídico (como es de suponer sucederá, al menos en vista de lo que sucede con los recursos de amparo), muy pocos asuntos podrán ser recurribles en casación y ese recurso acabará siendo testimonial (esperemos que eso no suceda por el bien de la Justicia). Ello haría aconsejable una reforma procesal para que fuera posible la apelación en todo caso.

La reforma supone, por tanto, un paso más, y muy importante, en la acreditada línea de tendencia restrictiva de estos recursos de casación que se ha venido mostrando norma tras norma, e interpretación tras interpretación, desde su creación por Ley 10/1992.

Si mis augurios se confirman, la reforma debería quizás, en su momento, dar lugar a la subsiguiente reducción del número de Magistrados de la Sala Tercera del Tribunal Supremo -salvo que fueran necesarios para la Sala de Admisión-, y al imprescindible incremento de los que sirvieran en los Juzgados y en los Tribunales Superiores de Justicia.

Habrá que estar pendientes de los criterios que vaya fijando el Tribunal Supremo en la aplicación del nuevo recurso de casación, y de las estadísticas sobre su actividad para poder alcanzar otras conclusiones sobre los efectos de esta reforma, cuya aplicación se presenta complicada tanto para los miembros del Tribunal Supremo como para los abogados.

La supresión de los recursos de casación para la unificación de la doctrina y en interés de ley ha sido a mi juicio un acierto parcial, pues la nueva casación no cubre suficientemente situaciones que esos recursos sí estaban llamados a proteger.

Es acertada la prevista publicación de ciertas resoluciones en la web del Tribunal Supremo (aunque no de todas, como sería deseable, y con mayor agilidad).

No lo ha sido, en cambio, la limitación de la extensión máxima de los escritos, que en algunos casos supondrá un reto para los abogados. 
Es por lo demás relevante el olvido que ha tenido el legislador a la hora de establecer una norma que aclarase el régimen de entrada en vigor de la reforma, y es cuestionable la aplicación que ha hecho del mismo el Tribunal Supremo de forma restrictiva. 